\title{
FLEXURAL BEHAVIOR OF HIGH STRENGTH FIBER REINFORCED CONCRETE BEAMS AS AFFECTED BY RIB GEOMETRY AND GRADE OF MAIN STEEL UNDER STATIC LOADS
}

\author{
Rashwan M. M. ; Hosny M. Soghair ; Aly Abdel-Zaher ELsayed \\ Civil Engineering Department, Faculty of Engineering, Assuit University, Assuit, \\ Egypt
}

\author{
Ali Mohamed Abdallah Abou-Zied ( Ph. D. Student) \\ General Authority of Educational Buildings, Sohag, Egypt
}

(Received February 19, 2006 Accepted April 8, 2006)

The need of high-performance concrete is increasing in recent years for the use in high rise building and the new breed of concrete gravity platforms for offshore structures. The use of high strength concrete needs high percentage of steel reinforcement to get the full capacity of the flexural strength of the member. Hence, the need of using high grade of steel reinforcement and different fibers to concrete mixes is necessary from the economical point of view. So, different ribs are used for the increase of bond strength between steel reinforcement and highperformance concrete. But these materials were brittle and the failure also was brittle. So, fibers are used to enhance their composite properties.

There is little information in the available literature about the flexural behavior of high-performance and high-performance fiber-reinforced concrete beams with different rib geometry under partial bond. Therefore, this paper focuses on the application of different types of fibers and steel rib geometry in the technology of high strength R.C. rectangular beams having $f c=900 \mathrm{~kg} / \mathrm{cm}^{2}$ and study their flexural behavior under static loading.

Test results showed that, the failure mode, cracks pattern and flexural behavior of high strength and fiber-high strength reinforced concrete beams were clearly affected by rib geometry and quality of the main steel and fibers type. The values of cracking and ultimate load carrying capacity of R.C. tested beams were increased with the increase of the grade of the main steel and its relative rib area $\left(F_{y}\right.$ from 3100 to $4750 \mathrm{~kg} / \mathrm{cm}^{2} \& \alpha_{s b}$ from 0.0 to 0.10 ) by about 65 \& $76 \%$ respectively for beams without fibers. Also, they were increased by about 80 \& $82 \%$ for beams with polypropylene fibers and by about 86 \& $83 \%$ for beams with harex steel fibers. The addition of fibers to concrete mixes of R.C. beams has greatly improved their ductility by increasing the ultimate strains under maximum compressive stresses and improved the crack propagation patterns for all tested (HPFRC) beams.

KEYWORDS: Rib geometry, Fibers, polypropylene, harex steel fibers, Flexural behavior, High-performance concrete, cracks pattern, failure mode 


\section{1-INTRODUCTION}

High strength concrete began to be developed in 1970 for the use in high rise buildings and the new breed of concrete gravity platforms for offshore structure. These developments have continued over the past twenty-years with concrete of 80,100 and $120 \mathrm{~N} / \mathrm{mm}^{2}$ and even higher. According to ACI building code [1], the maximum allowable percentage of reinforcement varies from $1 \%$ to $4.7 \%$ for normal strength concrete having $\mathrm{fc}=300 \mathrm{~kg} / \mathrm{cm}^{2}$ and steel with $\mathrm{fy}=2400 \mathrm{~kg} / \mathrm{cm}^{2}$. But, this percentage varies from $1 \%$ to $7 \%$ for high performance concrete having $\mathrm{fc}>800 \mathrm{~kg} / \mathrm{cm}^{2}$ and steel with $\mathrm{f}_{\mathrm{y}}=4000 \mathrm{~kg} / \mathrm{cm}^{2}$. So, the use of high strength concrete needs high percentage of steel reinforcement to get the full capacity of the flexural strength of the member. So, the need of using high grade of steel reinforcement and different fibers to concrete mixes is necessary from the economical point of view. Using steels of high grade maximizes the benefit of using this material. So, different ribs are used for the increase of bond strength between steel reinforcement and high-performance concrete. But these materials were brittle and their failure also was brittle .So, fibers are used to enhance composite properties. The enhanced properties include tensile strength, compressive strength, bond strength, elastic modulus, crack resistance, crack control, durability, fatigue life, resistance to impact and abrasion, shrinkage, expansion, thermal characteristics, and fire resistance [2, 3, 4].

High-performance Fiber-Reinforced Concrete (HPFRC) is a result of the addition of either short discrete fibers or continuous long fibers to the cement based matrix. Due to the superior performance characteristics of this category of (HPC), its use by the construction industry has significantly increased in the last 16 years. A very good guide to various Portland cement-based composites as well as their constituent materials is available in a published book "Balaguru and Shah 1992" [5]. The book provides information on fabrication, mechanical and long-term properties of concrete with short discrete fibers. It also covers special topics such as fiber-reinforced cements and slurryinfiltrated fiber concrete. In 1992, the first international workshop on high performance fiber reinforced cement composites (HPFRCC) was held in Mainz, Germany "Reinhardt and Naaman 1992" [6].

M. H. Harajli and M. E. Mabsout, 2002, [7] have studied the effect of fibers on the bond strength of deformed bars embedded in concrete . They have reported that, the use of fiber reinforcement significantly increases the development/splice strength and considerably enhances the ductility of bond failure. The increase in bond strength required using steel fibers may increase with levels substantially larger than the maximum limit stipulated in the ACI building code [1] for ordinary transverse reinforcement.

Experimental study on steel fiber-reinforced concrete beams were investigated by Magdy A. Tayel et al, 2003, [8] .They concluded that the addition of steel fibers to a concrete mix has increased the hardened concrete compressive and tensile strengths. And the addition of steel fibers in a very small ratio $=0.25 \%$ does not increase the concrete strengths.

The effect of rib geometry of steel reinforcement on bond of normal strength concrete was studied by Ali M.A., 2000, [9].He found that the final mode of failure, cracking and ultimate load and deformation of cantilever-to-column connection were affected 
by the relative rib area $\left(\alpha_{\mathrm{sb}}\right)$ and development length. The geometry of the ribs can be expressed by the relative rib area $\alpha_{\mathrm{sb}}$, which is described by Rehm [10] as $\boldsymbol{\alpha}_{\mathbf{s b}}$ (ratio of projected rib area normal to bar axis to the product of the nominal bar perimeter and the center-to-center rib spacing). Rehm[10], Soretz and Holzenbein[11], and Parviz [12] showed that the influence of the deformation pattern of bar on the local bond stress-slip behavior can reasonably be described as a function of the relative rib area for pullout specimens with normal concrete strength.The definition of the relative rib area $\boldsymbol{\alpha}_{\mathbf{s b}}$ is described by Rehm as shown in Fig. 1.

$$
\boldsymbol{\alpha}_{\mathbf{s b}}=\left(\mathrm{k} \cdot \mathrm{F}_{\mathrm{R}} \cdot \sin \beta\right) /\left(\pi \cdot \mathrm{db} \cdot \mathrm{c}_{\mathrm{s}}\right)
$$

Where :

$\mathrm{k}=$ number of transverse ribs around the bar perimeter

$\mathrm{db}=$ nominal diameter of bar , and $\mathrm{F}_{\mathrm{R}}=$ parabolic area of the transverse rib.
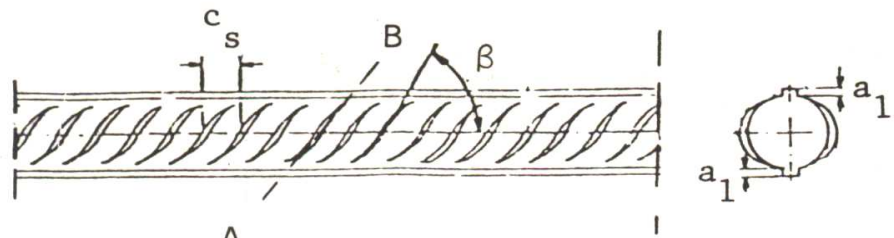

A

\section{a- Bar with inclined ribs}

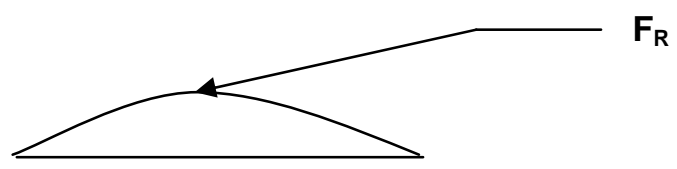

b- Rib section A-B

Fig. 1: Properties of the rib geometry of steel bar.

Since 1990, several studies have been conducted to investigate specifically the bond strength of reinforcement in high strength concrete. de Larrard et al. , 1993, [13] evaluated the bond strengh between high strength concrete and reinforcing bars using the RILEM beam test. A high strength concrete with 28-days compressive strength of $95 \mathrm{MPa}$ was used and a normal strength concrete of $42 \mathrm{MPa}$ used as a control. Three different sizes of deformed bars $(10,16,25 \mathrm{~mm})$ and one smooth bar $(25 \mathrm{~mm})$ were used. Based on several preliminary tests, the RILEM recommended bond (anchorage) length of 10 times bar diameter had to be reduced to 3 times to 2.5 times bar diameter for high strength concrete to ensure bond failure rather than yielding of reinforcement. So, this paper focuses on the application of different types of fibers and different grades of steel with different shapes of rib geometry in the technology of high strength R.C. rectangular beams having $\mathrm{f}_{\mathrm{c}}=900 \mathrm{~kg} / \mathrm{cm}^{2}$ under static loading.

\section{2- EXPERIMENTAL PROGRAM}

The main aim of this program is to investigate experimentally the behavior of high strength R.C. rectangular beams affected by fibers and grade of main steel with different types of rib geometry under static loads. 
The experimental approach in this study consisted of testing nine rectangular beams under static load. High strength concrete of about $900 \mathrm{~kg} / \mathrm{cm}^{2}$ compressive strength was used. All beams were tested at 28 days curing age. The beams were all identical in size, $12-\mathrm{cm}$ width and $30 \mathrm{~cm}$ overall depth. Bonded parts beyond the support $\left(\mathrm{L}_{1}\right)$ for steel reinforcement used in this study were $5 \mathrm{~d}_{\mathrm{b}}$ only for all beams. All beams were tested under two third points of loading on an effective span of $2.4 \mathrm{~ms}$, with shear span to effective depth ratio $\mathrm{a} / \mathrm{d}=3.0$. The steel reinforcement of all beams was $2 \varphi 16 \mathrm{~mm}$ as tension reinforcement, $2 \varphi 12 \mathrm{~mm}$ as compression reinforcement and closed stirrups of $10 \varphi 8 \mathrm{~mm} / \mathrm{m}$ ! Details of tested beams and reinforcement are shown in Fig. 2. The study takes into consideration the following variables:

1- Grade of the main steel represented by its yield stress $\left(F_{y}=3100,4600 \&\right.$ $4750 \mathrm{~kg} / \mathrm{cm}^{2}$ ),

2- Rib geometry of the main steel reinforcement used in the tested beams, which represented by its relative rib area $\left(\alpha_{\mathrm{sb}}=0.00,0.062 \& 0.10\right)$.

3- Type of fibers: two types of fibers (polypropylene, and steel fibers "harex") were used for all high strength fiber reinforced concrete beams.

The behavior of tested beams includes the initiation of cracks and their propagation, final mode of failure, relationship between applied flexural load and maximum induced deformation; in terms of deflection, slip, strain and end slope of (HPC) and (HPFRC) beams reinforced with steel having variable relative rib area $\left(\alpha_{\mathrm{sb}}\right)$ and modified with different types of fibers.
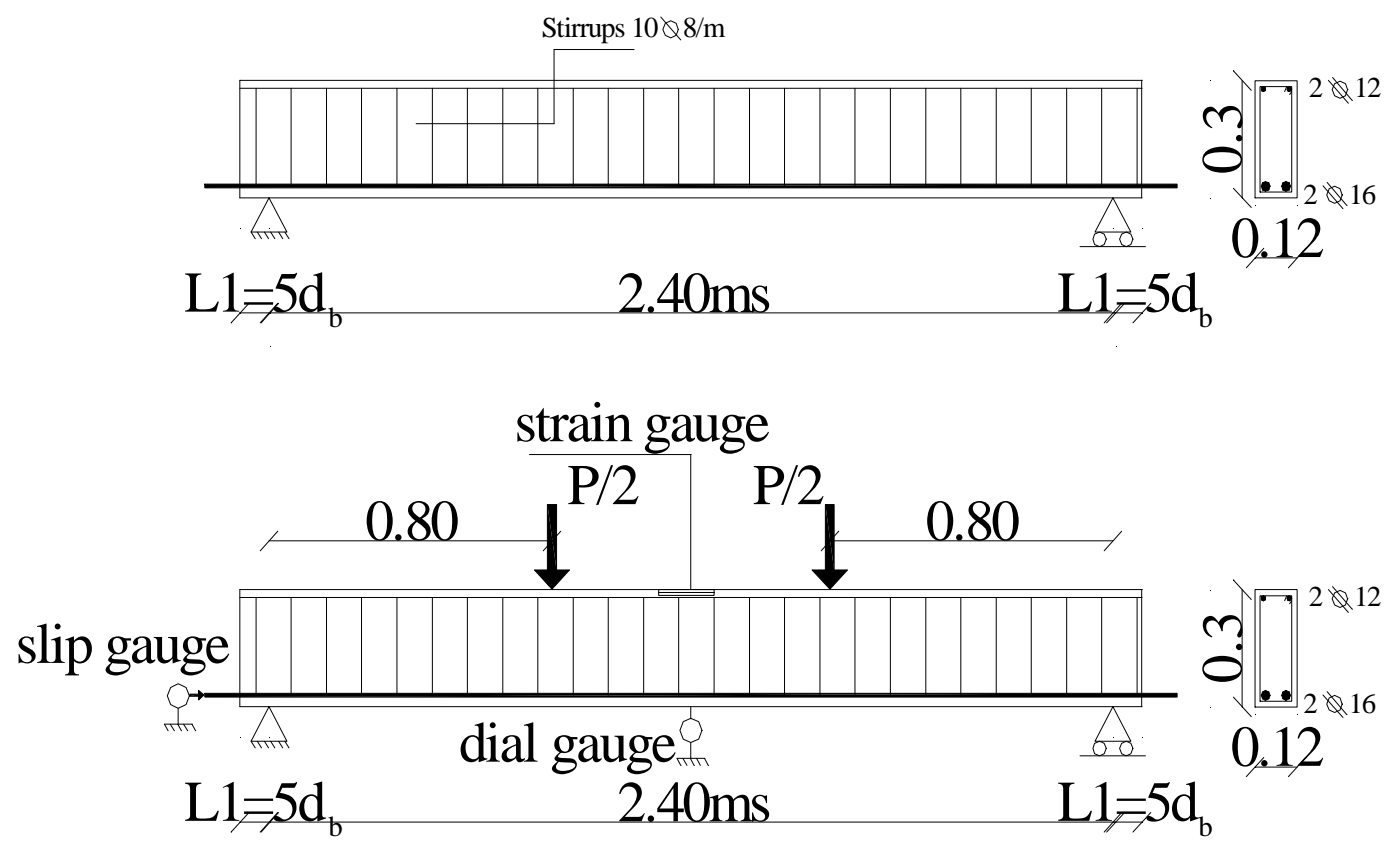

Fig. 2: Details of R.C. tested beams. 


\section{1- Materials}

\subsection{1- High Performance Concrete (HPC)}

Concrete mix design was made to produce high strength concrete of 28-days cubic strength of $900 \mathrm{~kg} / \mathrm{cm}^{2}$. Concrete mix proportions are given in Table 1.

Table 1: Concrete mix proportions.

\begin{tabular}{|c|c|c|c|c|c|}
\hline $\begin{array}{c}\text { Cement, } \\
\mathrm{kg} / \mathrm{m}^{3}\end{array}$ & $\begin{array}{c}\text { Fine } \\
\text { aggregate, } \\
\mathrm{kg} / \mathrm{m}^{3}\end{array}$ & $\begin{array}{c}\text { Coarse } \\
\text { aggregate, } \\
\mathrm{kg} / \mathrm{m}^{3}\end{array}$ & $\begin{array}{c}\text { Silica-fume, } \\
\mathrm{kg} / \mathrm{m}^{3}\end{array}$ & $\begin{array}{c}\text { Superplasticizer } \\
(\text { B.V.S.), } \\
\text { Litre } / \mathrm{m}^{3}\end{array}$ & $\begin{array}{c}\text { Water, } \\
\text { liter } / \mathrm{m}^{3}\end{array}$ \\
\hline 500 & 580 & 1200 & 110 & 17.5 & 140 \\
\hline
\end{tabular}

Ordinary Portland cement was used (Assiut Cement). The coarse aggregate used was crushed basalt of $12 \mathrm{~mm}$ nominal size. Local natural sand was used as fine aggregate; Superplasticizer (B.V.S.) type, with optimum dosage $17.5 \mathrm{litre} / \mathrm{m}^{3}$ for concrete mix; $110 \mathrm{~kg} / \mathrm{m}^{3}$ optimum dosage of silica fume with specific gravity $2.15 \mathrm{t} / \mathrm{m}^{3}$ were used.

\subsection{2- Steel Reinforcement}

Plain bars of normal mild steel ( $\mathrm{Fy}=3100 \mathrm{~kg} / \mathrm{cm}^{2}$ with $\alpha_{\mathrm{sb}}=0.00$ ) with diameters 8 and 16-mm used for stirrups and main steel in (HPC) and (HPFRC) beams. But deformed bars of high tensile strength $\left(\mathrm{Fy}=4600 \& 4750 \mathrm{~kg} / \mathrm{cm}^{2}\right.$ with $\alpha_{\mathrm{sb}}=0.062 \&$ 0.10 , respectively) were used as longitudinal tension /compression reinforcements with diameters of 16 and $12 \mathrm{~mm}$ in (HPFRC) beams. Details of steel reinforcement are given in Table 2.

\subsection{3 - High-Performance Fiber-Reinforced Concrete Properties (HPFRC)}

Six beams (group B\&C) of high performance fiber reinforced concrete of $900 \mathrm{~kg} / \mathrm{cm}^{2}$ were made from the same materials of (HPC) plus polypropylene (B1P, B2P, and B3P) and harex steel fibers (B1S,B2S,B3S). Typical properties of various types of the nonmetallic fiber (polypropylene fiber) and metallic fiber (harex steel fiber) are given in Table 3 and the shape of fibers is shown in Fig. 3. One fiber concentration only was used in the all tested beams and equals to $1.0 \%$ by volume of the total mix. This concentration of polypropylene is large but it was taken in this research for the comparison of results with the harex steel fibers.

Table 2: Mechanical and Geometrical Properties of Steel Bars.

\begin{tabular}{|c|c|c|c|c|c|c|c|}
\hline Group & Series & $\begin{array}{c}\text { Nominal } \\
d_{b}, m m\end{array}$ & $\begin{array}{c}\text { Bar } \\
\text { Notation }\end{array}$ & $\begin{array}{c}\text { Relative } \\
\text { Rib Area } \\
\left(\alpha_{\mathrm{sb}}\right)\end{array}$ & $\begin{array}{c}\text { Yield } \\
\text { stress }\left(\mathrm{F}_{\mathrm{y}}\right) \\
\mathrm{kg} / \mathrm{cm}^{2}\end{array}$ & $\begin{array}{l}\text { Ultimate } \\
\text { strength } \\
\left(\mathrm{F}_{\mathrm{u}}\right) \mathrm{kg} / \mathrm{cm}^{2}\end{array}$ & $\begin{array}{c}\% \\
\text { Elongation }\end{array}$ \\
\hline \multirow{3}{*}{$\begin{array}{c}\mathrm{A} \\
\& \\
\mathrm{~B} \\
\text { and } \\
\mathrm{C}\end{array}$} & \multirow{3}{*}{$\begin{array}{c}\mathrm{B} 1, \mathrm{~B} 2, \mathrm{~B} 3 \\
\& \\
\mathrm{~B} 1 \mathrm{P}, \mathrm{B} 2 \mathrm{P}, \mathrm{B} 3 \mathrm{P} \\
\text { and } \\
\mathrm{B} 1 \mathrm{~S}, \mathrm{~B} 2 \mathrm{~S}, \mathrm{~B} 3 \mathrm{~S}\end{array}$} & \multirow[b]{3}{*}{16} & Sm & 0.000 & 3100 & 4600 & 28.6 \\
\hline & & & BlS & 0.062 & 4600 & 6700 & 19.2 \\
\hline & & & $\mathrm{EZ} \cdot \mathrm{AL} 2$ & 0.100 & 4750 & 6900 & 18.5 \\
\hline \multicolumn{2}{|c|}{ Top steel } & 12 & EZAL & 0.060 & 4600 & 6700 & 22.0 \\
\hline \multicolumn{2}{|r|}{ Stirrups } & 8 & Sm* & 0.000 & 2900 & 4200 & 29.5 \\
\hline
\end{tabular}


Table 3 : Typical properties of fibers .

\begin{tabular}{|c|c|c|c|c|c|c|}
\hline Type of fibers & $\begin{array}{c}\text { Diameter, } \\
(\mu \mathrm{m})\end{array}$ & $\begin{array}{c}\text { Length } \\
,(\mathrm{mm})\end{array}$ & $\begin{array}{c}\text { Density, } \\
\left(\mathrm{gm} / \mathrm{cm}^{3}\right)\end{array}$ & $\begin{array}{c}\text { Tensile } \\
\text { Strength, } \\
\mathrm{kg} / \mathrm{cm}^{2}\end{array}$ & $\begin{array}{c}\text { Young's } \\
\text { modulus, } \\
\mathrm{kg} / \mathrm{cm}^{2}\end{array}$ & $\begin{array}{c}\text { Elongation, } \\
(\%)\end{array}$ \\
\hline Polypropylene & $2-20$ & 18 & 0.91 & 5000 & 50000 & $8-10$ \\
\hline Harex steel & 1000 & 32 & 7.8 & 20000 & 2000000 & 3 \\
\hline
\end{tabular}

Properties of harex steel fiber locally produced by chemicals for modern building CEM Co. But polypropylene fiber produced by Sika Co. in Italy

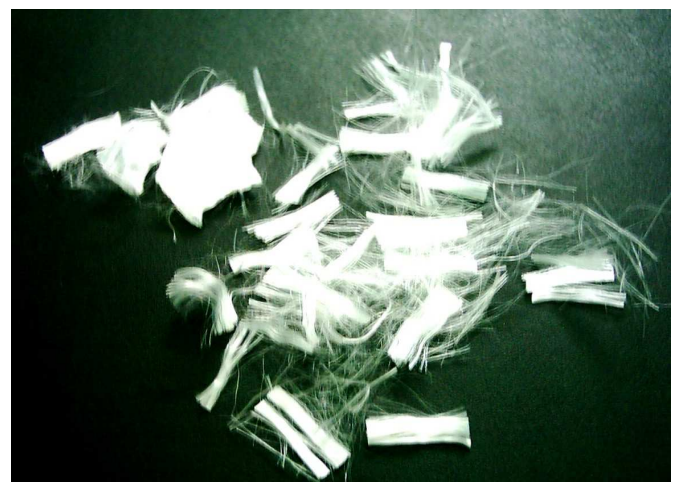

a-Polypropylene fiber

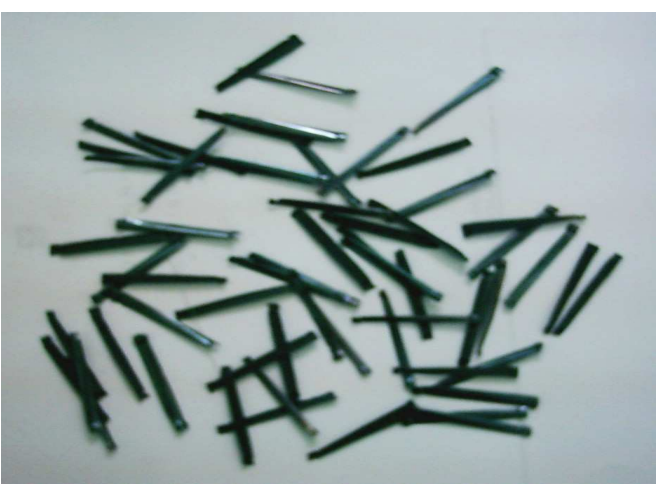

b-Harex steel fiber

Fig. 3: Shape of metallic and non-metallic fibers.

\subsection{Test Procedure}

Nine R.C. beams of 28 days age were tested, simply supported over a clear span of $2.4 \mathrm{~ms}$, under two third-points of loading. The available testing machine (EMS 60 tons $\mathrm{Pu}$ ) was used in testing the beams specimens under static loading. Average values of 28-days concrete compressive strength determined from cubes of $15 \mathrm{~cm}$ side length were $\left(907,900\right.$ and $918 \mathrm{~kg} / \mathrm{cm}^{2}$ ) for (HPC) beams without fibers, (HPFRC) beams with polypropylene fibers and harex steel fibers respectively. The beams deflection was measured using dial gauges with accuracy of $0.01 \mathrm{~mm}$ at the bottom surface of testing beams at mid span. Strains of concrete were measured at the top surface of tested beams at the mid span using electrical strain gauges having effective length of $50 \mathrm{~mm}$. The load was applied in an increment of 0.5 ton up to failure load. After each increment, reading of strain gauges, dial gauge, and crack propagation were recorded.

\section{3- TEST RESULTS}

\section{1- Effect Of The Shape Of Rib Geometry On The Properties Of Steel Bars And Their Ultimate Bond Strength}

The effect of different shapes of rib geometry, represented by relative rib area $\left(\alpha_{\mathrm{sb}}\right)$, on the mechanical properties of different types of steel bars of nominal diameter $16 \mathrm{~mm}$ and their ultimate bond strength for different bonded lengths was 
studied. Also, the influence of different shapes of rib geometry, represented by relative rib area on the ultimate bond strength of different types of steel bas of the same nominal diameter was studied by using pull-out prismatic specimens of square section $12 \times 12 \mathrm{cms}$ with cubic strength $900 \mathrm{~kg} / \mathrm{cm}^{2}$, which were tested with $16 \mathrm{~mm}$ embedded steel bar of different bonded lengths of $5 \mathrm{~d}_{\mathrm{b}}, 7.5 \mathrm{~d}_{\mathrm{b}} \& 10 \mathrm{~d}_{\mathrm{b}}$ and the results are shown in Table 4. From Table 4, it is clear that the shape of rib geometry of steel bars represented by its relative rib area $\left(\alpha_{\mathrm{sb}}\right)$ has a very small effect on their mechanical properties especially yield stress and ultimate strength. But, this shape of rib geometry has a clear influence on the ultimate bond strength of tested specimens, which increased by the increase of the relative rib area and not mainly depended on the yield stress only of steel bars. For example, by the comparison of bar type EZ.AL1 (Fy = $\left.4750 \mathrm{~kg} / \mathrm{cm}^{2} \& \alpha_{\mathrm{sb}}=0.07\right)$ with bar type BS5 $\left(\mathrm{Fy}=4300 \mathrm{~kg} / \mathrm{cm}^{2} \& \alpha_{\mathrm{sb}}=0.093\right)$ it is clear that, the ultimate bond strength of specimen with bar BS5, of low yield stress, equals $224.9 \mathrm{~kg} / \mathrm{cm}^{2}$. But, it equals $208.39 \mathrm{~kg} / \mathrm{cm}^{2}$ for specimen with bar EZ.AL1 of high yield stress. This means that the main influence on the ultimate bond strength depends on the rib geometry of the bars, which did not reach the yield point.

Table 4: Mechanical and geometrical properties of deformed Bars and their effect on the ultimate bond strength of high strength concrete prismatic specimens.

\begin{tabular}{|c|c|c|c|c|c|c|c|c|}
\hline \multirow[t]{2}{*}{$\begin{array}{c}\text { Nominal } \\
\mathrm{d}_{\mathrm{b}}, \mathrm{mm}\end{array}$} & \multirow[t]{2}{*}{$\begin{array}{l}\text { Type of } \\
\text { bars }\end{array}$} & \multirow{2}{*}{$\begin{array}{l}\text { Relative } \\
\text { Rib Area } \\
\qquad\left(\alpha_{\mathrm{sb}}\right)\end{array}$} & \multirow{2}{*}{$\begin{array}{l}\text { Yield } \\
\text { stress } \\
\mathrm{kg} / \mathrm{cm}^{2} \\
\left(\mathrm{~F}_{\mathrm{y}}\right)\end{array}$} & \multirow{2}{*}{$\begin{array}{l}\text { Ultimate } \\
\text { strength } \\
\mathrm{kg} / \mathrm{cm}^{2} \\
\left(\mathrm{~F}_{\mathrm{u}}\right)\end{array}$} & \multirow[t]{2}{*}{$\begin{array}{c}\% \\
\text { Elongation }\end{array}$} & \multicolumn{3}{|c|}{$\begin{array}{c}\text { ultimate bond strength } \\
\left(\mathrm{F}_{\mathrm{bu}}\right), \mathrm{kg} / \mathrm{cm}^{2} \text { for different } \\
\text { bonded lengths }\end{array}$} \\
\hline & & & & & & $5 \mathrm{db}$ & $7.5 \mathrm{db}$ & $10 \mathrm{db}$ \\
\hline \multirow{15}{*}{16} & $\mathrm{Sm}$ & 0.000 & 3100 & 4600 & 28.6 & 96.61 & 92.92 & 88.16 \\
\hline & Lxx & 0.030 & 4600 & 6940 & 22.4 & 179.5 & 171.42 & 159.4 \\
\hline & BS & 0.045 & 4360 & 6880 & 19.9 & 190.0 & 181.62 & 168.23 \\
\hline & EZ & 0.060 & 4700 & 6990 & 20.3 & 200.8 & 192.15 & 192.15 \\
\hline & $\mathrm{B} \backslash \mathrm{S}$ & 0.062 & 4600 & 6700 & 19.2 & 201.92 & 192.56 & 192.56 \\
\hline & EZ1AL & 0.065 & 4500 & 6675 & 19.7 & 204.81 & 193.72 & 193.72 \\
\hline & EZ-AL & 0.069 & 4600 & 6650 & 19.3 & 206.9 & 194.71 & 194.71 \\
\hline & EZ.AL1 & 0.070 & 4750 & 6700 & 18.6 & 208.39 & 195.29 & 195.29 \\
\hline & ARSL & 0.072 & 4600 & 6750 & 18.4 & 210.5 & 196.2 & 196.2 \\
\hline & NS & 0.073 & 4400 & 6450 & 18.6 & 211.3 & 196.54 & 196.54 \\
\hline & $\mathrm{TS}$ & 0.076 & 4450 & 6550 & 19.0 & 212.6 & 196.87 & 196.87 \\
\hline & DK2 & 0.078 & 4550 & 6800 & 19.5 & 215.0 & 197.8 & 197.8 \\
\hline & DK1 & 0.090 & 4450 & 6200 & 20.5 & 222.0 & 203.1 & 203.1 \\
\hline & BS5 & 0.093 & 4300 & 6190 & 18.8 & 224.9 & 204.91 & 204.91 \\
\hline & EZ.AL2 & 0.100 & 4750 & 6900 & 18.5 & 231.35 & 209.39 & 209.39 \\
\hline
\end{tabular}




\section{2- Cracks Pattern And Mode Of Failure Of Tested Beams}

Cracks pattern and modes of failure are shown in Figs. $\mathbf{4}$ and $\mathbf{5}$ for the tested reinforced high-performance concrete (HPC) and high-performance fiber-reinforced concrete (HPFRC) beams. Three (HPC) beams and six rectangular (HPFRC) beams were tested under static loading. Generally, three types of final mode failure can be distinguished according to the relative rib area $\left(\alpha_{\mathrm{sb}}\right)$ and fiber types as bond failure (Pullout), bond-flexural failure or flexural failure.

The effect of the various parameters on the cracks and final modes of failure for beams will be discussed as follows.

\subsubsection{Effect of grade of steel and its relative rib area $\left(\alpha_{\mathrm{sb}}\right)$}

The following noted cracks for tested beams were observed as follows:

- The initiation of cracks were observed at smooth bar of low yield stress $\left(\mathrm{F}_{\mathrm{y}}=\right.$ $\left.3100 \mathrm{~kg} / \mathrm{cm}^{2}\right)$ or small value of $\left(\alpha_{\mathrm{sb}}=0.00\right)$ for beams $(\mathrm{B} 1, \mathrm{~B} 1 \mathrm{P}, \mathrm{B} 1 \mathrm{~S})$ and for beams $(B 3, B 3 P, B 3 S)$ at greater values of yield stress $\left(F_{y}=4750 \mathrm{~kg} / \mathrm{cm}^{2}\right)$ and relative rib area of $\left(\alpha_{\mathrm{sb}}=0.10\right)$.

- The width of cracks and spacing between them were significantly large for beams (B1, B1P, B1S) having smooth bars, but narrow for others having ribbed bars.

- The propagation of cracks for beams (B3, B3P, B3S) and (B2, B2P, B2S) were more than those compared to beams (B1, B1P, B1S).

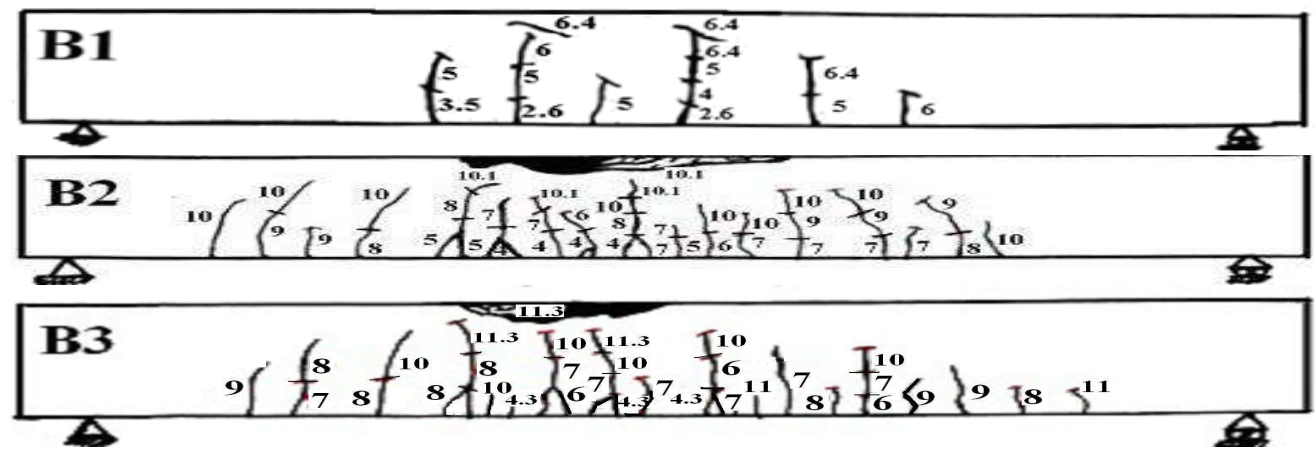

Fig. 4a: Cracks pattern of R.C. beams without fibers (B1,B2 and B3).
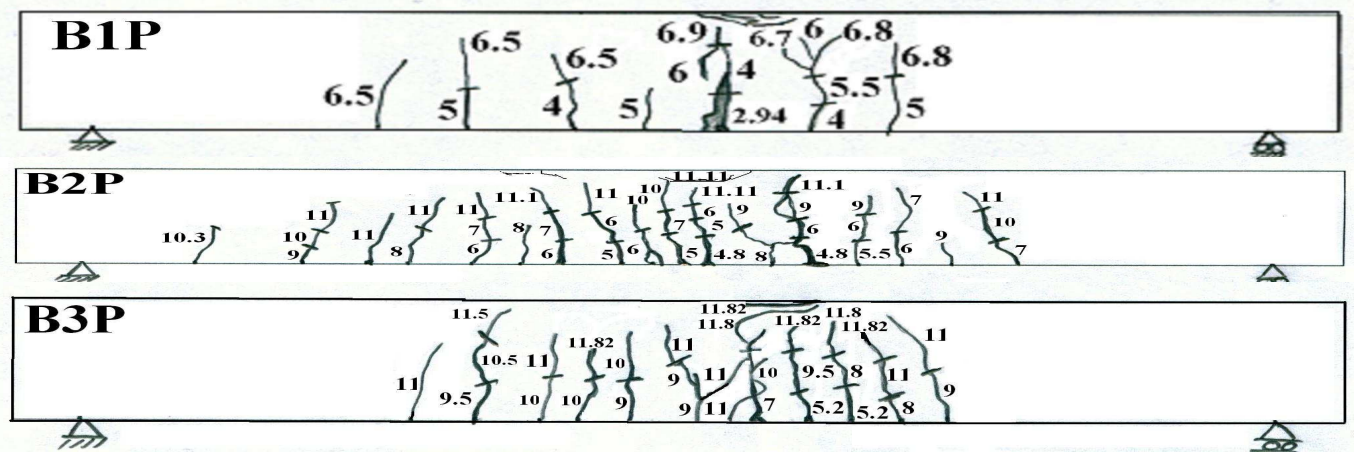

Fig. 4b: Cracks pattern of R.C. beams with polypropylene fibers (B1P, B1P \& B3P). 

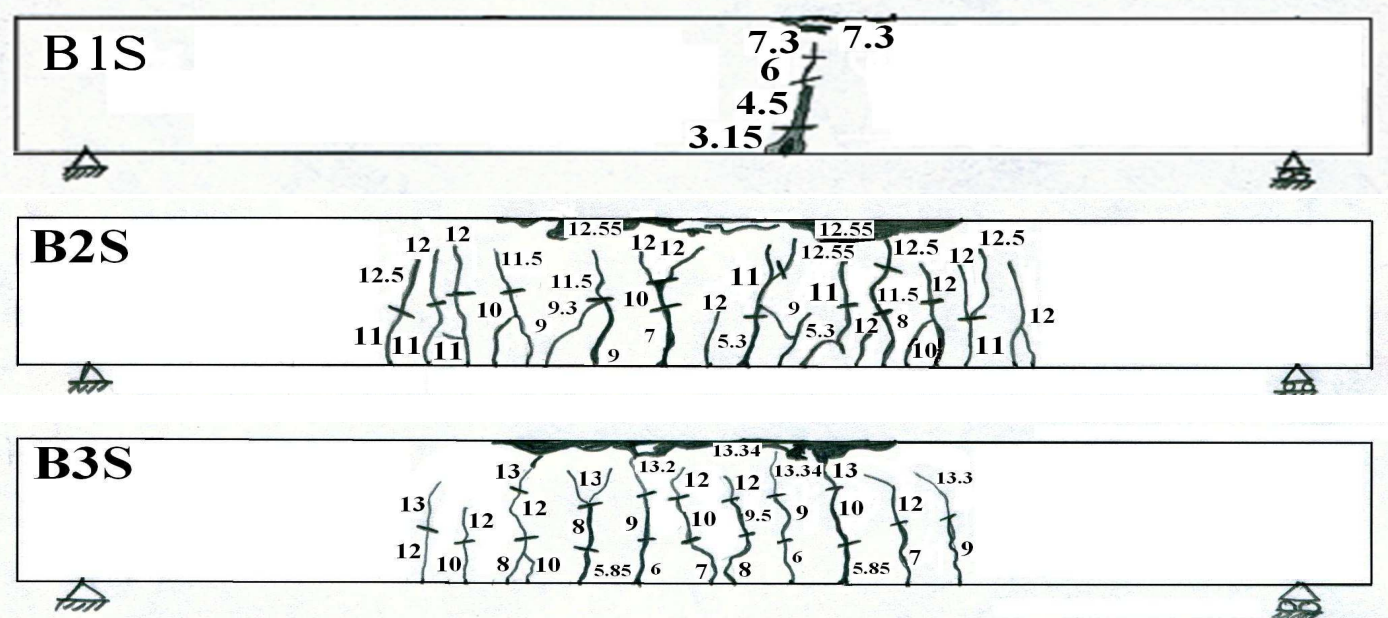

Fig. 4c: Cracks pattern of R.C. beams with harex steel fibers (B1S, B2S and B3S).

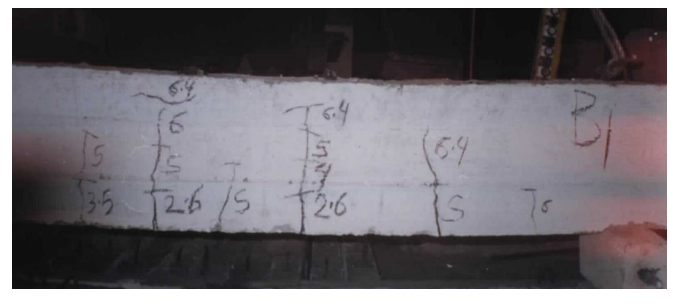

Fig. 5a: Failure shape of beam (B1).

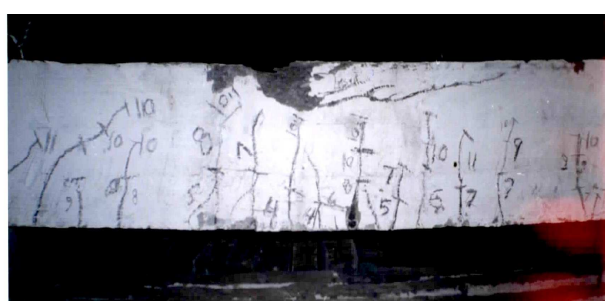

Fig.5b: Failure shape of beam (B2).

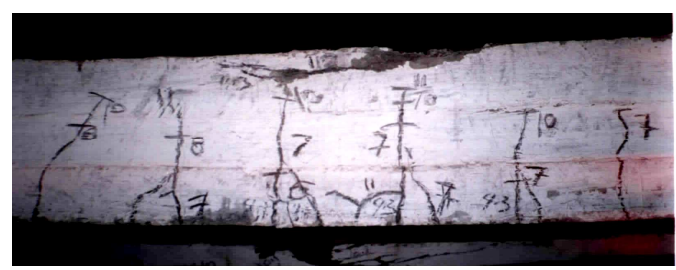

Fig.5c: Failure shape of beam (B3).

- The major cracks were formed in the tension zone at the maximum moment for all beams (at mid span of beams).

- The final modes of failure of beams (B1, B1P, B1S) with smooth bars were noticed to be bond-flexural failure, and for ribbed bars with relative rib area $\left(\alpha_{\mathbf{s b}}\right)=0.062$ \& 0.10 as for beams (B2, B2P, B2S, B3, B3P \&B3S) were noticed to be flexural failure. 


\subsubsection{Effect of fiber type}

The following noted cracks for beams were observed as follows:

- The initiation of cracks were observed for beams without fibers (B1, B2, B3) and for beams with polypropylene fibers (B1P, B2P, B3P) or harex steel fibers (B1S, $\mathrm{B} 2 \mathrm{~S}, \mathrm{~B} 3 \mathrm{~S})$ at the maximum moment in the tension zone.

- The propagation of cracks for beams (B1S, B2S, B3S) were less than those compared to beams (B1P, B2P, B3P), which were less than those compared to beams (B1, B2, B3).

- The major cracks were formed at the maximum moment for all tested beams (at mid span).

- The final modes of failure for beams (B1, B1P, B1S) with smooth bars were noticed to be bond-flexural failure, and for ribbed bars with relative rib area $\left(\alpha_{\mathbf{s b}}\right)=$ $0.062 \& 0.10$ as for beams (B2, B2P, B2S, B3, B3P \& B3S) were noticed to be flexural failure as shown in Figs. 4, 5 and 6.

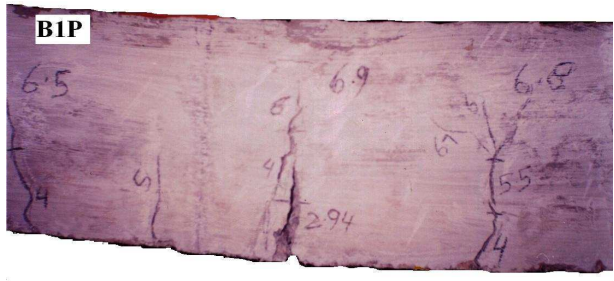

Fig. 6a: Failure shape of beam (BIP).

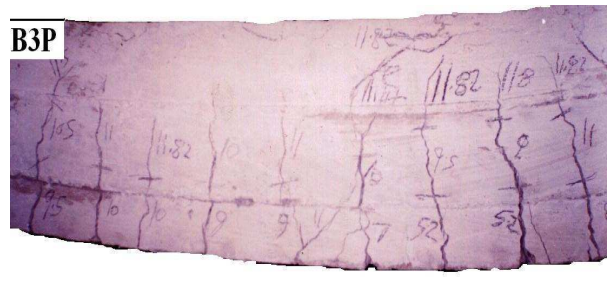

Fig. 6c: Failure shape of beam (B3P).

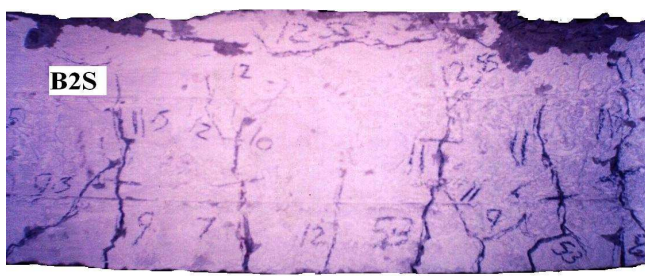

Fig. 6e: Failure shape of beam (B2S).

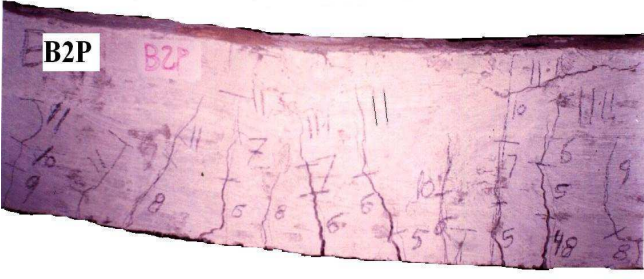

Fig. 6b: Failure shape of beam (B2P).

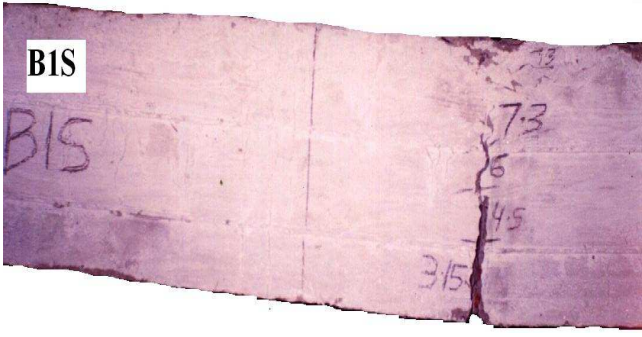

Fig. 6d: Failure shape of beam (B1S).

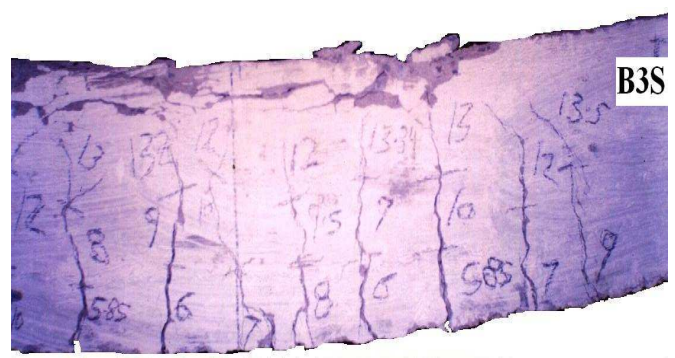

Fig. 6f: Failure shape of beam (B3S). 


\section{3-3 Measured Deformations}

The flexural load-mid span deflection; load-end slip; load-concrete strain and load-end slope curves obtained from tests are shown in Figs. 7 to 9 . The effect of the various parameters on the load-mid span deformation characteristics will be discussed as follows.

\subsubsection{Load - mid span deflection}

The measured and theoretical values of mid span deflection of tested beams are plotted versus applied load up to failure as shown in Fig. 7. All plotted values indicated that, the deflection increases as the applied load increases up to the ultimate load for all beams. Then, the beams started to show the sign of failure and the slope of the loaddeflection curve becomes flat or horizontal straight line and the deflection increased with or without decrease of loads for beams with fibers. The relation between the applied load and the mid span deflection tends to be in linear or non linear relation depending on the applied load level. The relation depends mainly on the grade of the main steel and its relative rib area $\left(\alpha_{\mathrm{sb}}\right)$, as well as the fiber type. The theoretical central deflection at all loads was calculated only for (HSC) beams without fiber by using $\mathrm{ACI}[1]$ equations as:

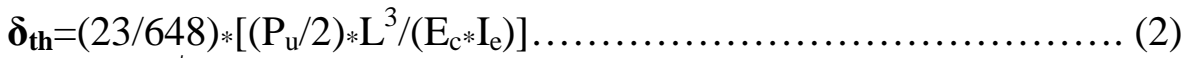

$$
\begin{aligned}
& \mathrm{E}_{\mathrm{c}}=3320 \sqrt{f_{\mathrm{c}}^{\prime}}+6900 \mathrm{Mpa} \\
& \mathrm{I}_{\mathrm{e}}=\left(\mathrm{M}_{\mathrm{cr}} / \mathrm{M}_{\mathrm{a}}\right)^{3} \mathrm{I}_{\mathrm{g}}+\left(1-\left(\mathrm{M}_{\mathrm{cr}} / \mathrm{M}_{\mathrm{a}}\right)^{3} \mathrm{I}_{\mathrm{cr}}\right) \\
& \mathrm{M}_{\mathrm{cr}}=\left(\mathrm{f}_{\mathrm{ctr}} \cdot \mathrm{I}_{\mathrm{g}}\right) / \mathrm{y}_{\mathrm{ct}}, \mathrm{f}_{\mathrm{ctr}}=0.94 \sqrt{ } \mathrm{f}_{\mathrm{c}}^{\prime} \mathrm{Mpa}, \mathrm{I}_{\mathrm{g}}=\mathrm{bt}^{3} / 12, \mathrm{y}_{\mathrm{ct}}=\mathrm{t} / 2, \mathrm{~b}=12 \mathrm{~cm}, \mathrm{t}=30 \mathrm{~cm}
\end{aligned}
$$

\section{- Effect of grade of the main steel and its relative rib area $\left(\alpha_{S b}\right)$}

The values of the applied load for all tested beams increased with the increase of grade of steel reinforcement and its relative rib area $\left(\alpha_{\mathrm{sb}}\right)$. Generally, the shape of the loadmid span deflection curve of tested beams reinforced with bars of low grade and small relative rib area $\left(\alpha_{\mathrm{sb}}\right)$ differs than that of tested beams with high grade of steel and high relative rib area $\left(\alpha_{\mathrm{sb}}\right)$. At the same value of deflection of $1.0 \mathrm{~mm}$ for beams (B1, B2 \& B3), the applied load increased respectively from 5.5 ton to $9.0 \& 10.5$ tons. This means that the increase of grade of steel from fy $=3100$ to $4750 \mathrm{~kg} / \mathrm{cm}^{2}$ and its relative rib area from 0.0 to 0.10 increased the applied load at the same deflection by about $90 \%$.

\section{- Effect of fibers type}

The values of the applied load at all values of deflections for beams modified with polypropylene fibers were more than that values of beams without fibers. And the values of the applied load at all values of deflections for beams modified with harex steel fibers were more than that values of beams with polypropylene fibers. For high performance concrete, the failure of beams without fibers was more brittle. But For high performance fiber reinforced concrete, the failure of beams was ductile, as shown in Fig. 7. At the same value of deflection of $1.0 \mathrm{~mm}$ for beams with harex steel fibers (B1S, B2S \&B3S), the applied load increased respectively from 6.8 ton to 11.5 $\& 13.2$ tons. This means that the increase of grade of steel from Fy $=3100$ to $4750 \mathrm{~kg} / \mathrm{cm}^{2}$ and its relative rib area from 0.0 to 0.10 increased the applied load at the 
same deflection by about $94 \%$. This type of fiber increased applied load at the same deflection by about $26 \%$ for beams with ribbed bars and by about $23 \%$ for beams with smooth bars.

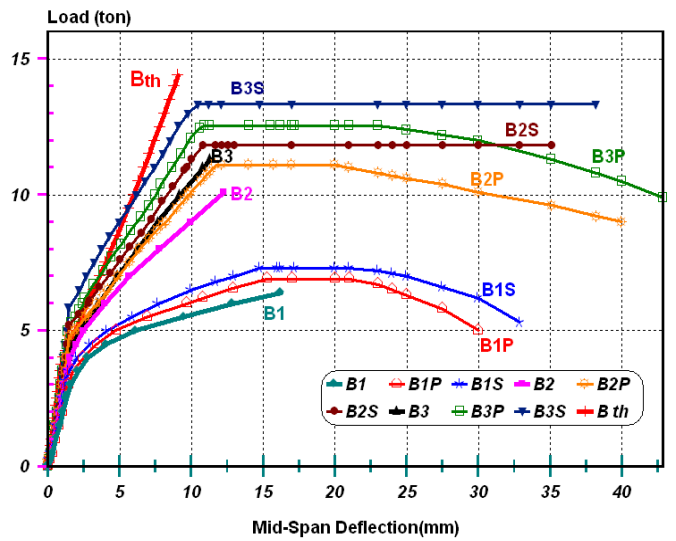

Fig. 7: Load versus mid span deflection for tested beams with and without fibers.

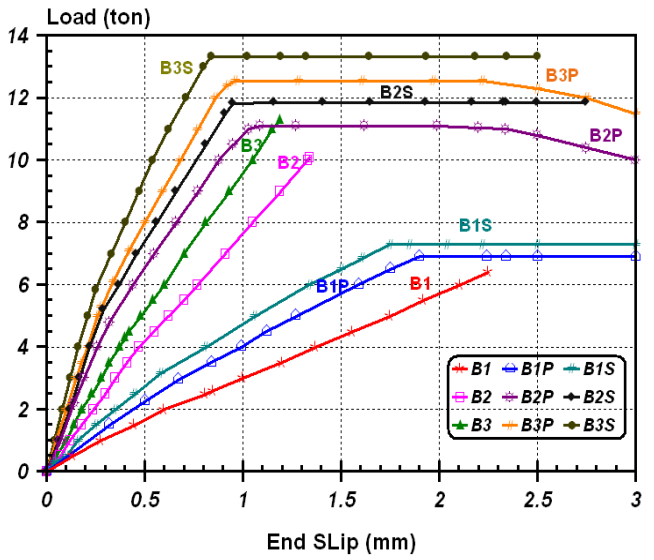

Fig. 8: Load - end slip relationship for tested beams with and without fibers.

\section{3. 2 Load - end slip relationship}

Stresses for concrete and steel are transferred between the two materials if they work together in beams. The term "bond" is used to describe the means by which slip between concrete and steel is prevented or minimized wherever the tensile or compressive stress in a bar changes or not. Bond stresses must act along the surface of the bar to produce the change. Deformed bars have larger bond capacity because of the interlocking of the ribs with the surrounding concrete .The mechanism of bond is comprised of three main components: chemical adhesion, friction, and mechanical interlock between bar ribs and concrete measured. The measured slip of main steel for all tested beams is plotted against applied load up to failure as shown in Fig. 8.

\section{- Effect of grade of main steel and its relative rib area $\left(\alpha_{s b}\right)$}

The measured values of the slip for all tested beams indicated that, the end slips decrease with the increase of the grade of steel and its relative rib area $\left(\alpha_{\mathrm{sb}}\right)$. Also, the load carrying capacity increases with the increase of the grade of steel and its relative rib area $\left(\alpha_{\mathrm{sb}}\right)$. At the same value of slip of $1.0 \mathrm{~mm}$ for beams (B1, B2 \& B3), the applied load increased respectively from 3 ton to $7.75 \& 9.5$ tons. This means that the increase of grade of steel from fy $=3100$ to $4750 \mathrm{~kg} / \mathrm{cm}^{2}$ and its relative rib area from 0.0 to 0.10 increased the applied load at the same slip by about $217 \%$.

\section{- Effect of fibers type}

The measured loads for tested beams group (C) having harex steel fibers were larger than that measured for group (B) having polypropylene fibers. A1so, the measured loads for group (B) having polypropylene fibers were larger than that measured for group (A) without fibers as shown in Fig. 8. The measured end slip of steel bars 
decreased for beams with fibers. At the same value of slip of $1.0 \mathrm{~mm}$ for beams with harex steel fibers (B1S, B2S \&B3S), the applied load increased respectively from 4.75 ton to $11.8 \& 13.4$ tons. This means that the increase of grade of steel from $\mathrm{Fy}=$ 3100 to $4750 \mathrm{~kg} / \mathrm{cm}^{2}$ and its relative rib area from 0.0 to 0.10 increased the applied load at the same slip by about $182 \%$. This type of fiber increased applied load at the same slip by about $41 \%$ for beams with ribbed bars and by about $57 \%$ for beams with smooth bars.

\section{3. 3 Concrete strain}

The measured values of concrete strain at the top surface of the compression zone of tested beams are plotted versus applied load from starting loading up to failure as shown in Fig. 9. Generally, the compressive concrete strain increases as the applied load increases up to the ultimate loads.The rate of increase of compressive concrete strain depends on the grade of steel reinforcement and its relative rib area $\left(\alpha_{\mathrm{sb}}\right)$ and the fibers type. The effect of these parameters can be observed from such curves.

\section{- Effect of grade of the main steel and its relative rib area $\left(\alpha_{s b}\right)$}

The measured values of the concrete strain for all tested beams in group (A), (B) and (C) decrease with the increase of the grade of steel reinforcement and its relative rib area $\left(\alpha_{\mathrm{sb}}\right)$. At the same value of concrete strain of $2 \times 10^{-3}$ for beams (B1, B2 \&B3), the applied load increased respectively from 6.5 ton to $10 \& 11$ tons. This means that the increase of grade of steel from fy=3100 to $4750 \mathrm{~kg} / \mathrm{cm}^{2}$ and its relative rib area from 0.0 to 0.10 increased the applied at the same strain by about $69 \%$.

\section{- Effect of fibers type}

The measured values of compressive concrete strain for all tested beams of group (A) increase than that of beams with the use of fibers (group B \& C) as shown in Fig. 9. At the same value of concrete strain of $2 \times 10^{-3}$ for beams with harex steel fibers (B1S, B2S $\& \mathrm{~B} 3 \mathrm{~S})$, the applied load increased respectively from 7 ton to $11.9 \& 13.2$ tons. This means that the increase of grade of steel from $F y=3100$ to $4750 \mathrm{~kg} / \mathrm{cm}^{2}$ and its relative rib area from 0.0 to 0.10 increased the applied at the same strain by about $88 \%$. This type of fiber increased applied load at the same concrete strain by about $20 \%$ for beams with ribbed bars and by about $8 \%$ for beams with smooth bars.

\section{3. 4 Load-slope characteristics}

The maximum measured slope at the center of hinged support of the beams is plotted versus the applied load from zero loading up to failure as shown in Fig. 10. Generally, the slope at the center of hinged support increases as the applied load increases up to limit of cracking load. Beyond this limit a sharp decrease in the rate of increase of the ultimate slope was observed and after that increasing in the slope was accompanied by a slight increasing of the applied load up to ultimate load for all beams. Then starting from the ultimate load, the beams started to show the sign of failure and the slope of the load- slope curve becomes flat from top to bottom or horizontal straight line and the slope increased with or without decrease of the loads for beams with fibers. The effect of the studied variables on the load-end slope will be discussed as follows: 


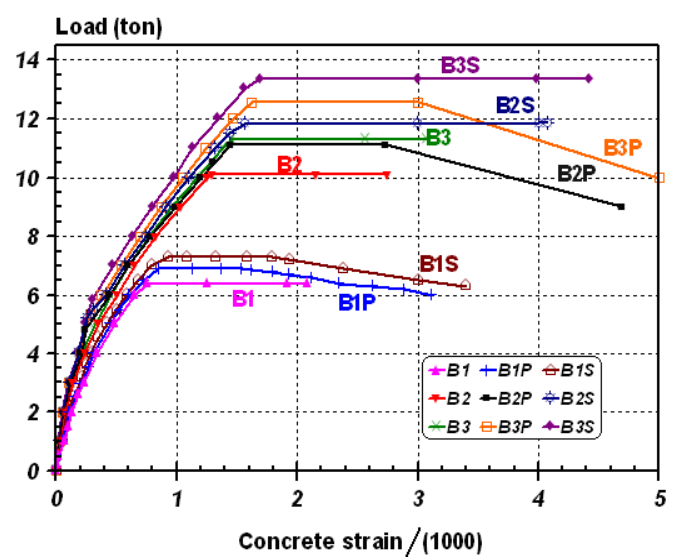

Fig. 9: Load-Compressive concrete strain at mid span relationship for tested beams.

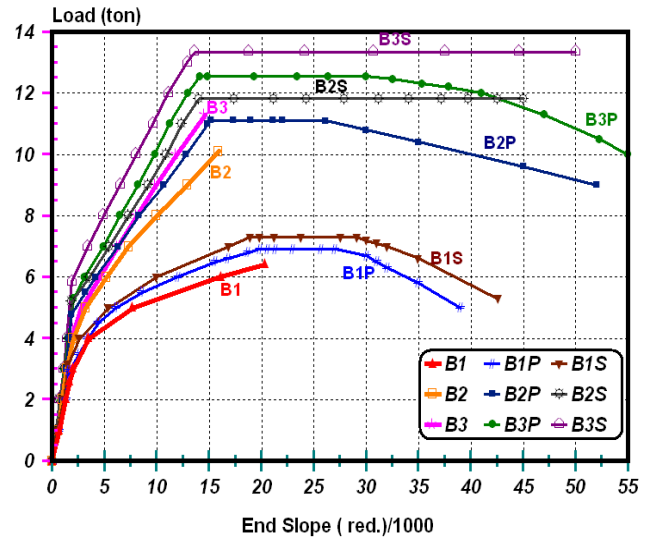

Fig. 10: Load- end slope relationship for all R.C. tested beams.

\section{- Effect of grad of the main steel and its relative rib area $\left(\alpha_{s b}\right)$}

The values of slope for all tested beams in groups (A), (B) and (C) decrease with the increase of the value of grade of steel and its relative rib area $\left(\alpha_{\mathrm{sb}}\right)$ due to the increase of the yield stress of steel reinforcement and bond between the steel and concrete. At the same value of slope of $1.5 \times 10^{-3}$ for beams (B1, B2 \& B3), the applied load increased respectively from 5.8 ton to $9.8 \& 11.4$ tons. This means that the increase of grade of steel from fy=3100 to $4750 \mathrm{~kg} / \mathrm{cm}^{2}$ and its relative rib area from 0.0 to 0.10 increased the applied at the same slope by about $96 \%$.

\section{- Effect of fibers type}

The values of end slope for all tested beams in groups (B \& C) with the used fibers were less than for beams in group (A) as a result of increasing quality of concrete and bond stresses between main steel and concrete. At the same value of slope of $1.5 \times 10^{-3}$ for beams with harex steel fibers (B1S, B2S \& B3S), the applied load increased respectively from 6.7 ton to $11.8 \& 13.3$ tons. This means that the increase of grade of steel from $F y=3100$ to $4750 \mathrm{~kg} / \mathrm{cm}^{2}$ and its relative rib area from 0.0 to 0.10 increased the applied at the same slope by about $98 \%$. This type of fiber increased applied load at the same slope by about $17 \%$ for beams with ribbed bars and by about $16 \%$ for beams with smooth bars.

\section{DISCUSSIONS OF RESULTS}

This item describes and interprets the analysis of the obtained test results of the HPC and HPFRC beams. The analysis includes the relationship between the values of the cracking and ultimate loads, slips, deflections, concrete strains and slope versus grade of steel represented by its yield stress or its relative rib area of bars $\left(\alpha_{\mathrm{sb}}\right)$ and the used fibers type.

\subsection{Cracking and Ultimate Loads}

The values of the obtained cracking (Pcr) and ultimate loads $(\mathrm{Pu})$ for tested beams are given in Table 5. The theoretical values of the ultimate load $\left(\mathrm{Pu}_{\mathrm{th}}\right)$ can be determined 
according to the smallest value of the following cases (a)- due to bending, (b)- due to shear or(c)-due to bond. The critical case was due to bending as follow by "ACI code 1995" [1]:

$\mathrm{Mu}=$ As. $f_{\mathrm{y}} \cdot \mathrm{d}\left(1-0.59 \rho f_{\mathrm{y}} / f^{\prime} \mathrm{c}\right), f^{\prime} \mathrm{c}=0.9 \mathrm{fc}, \mathrm{Pu}_{\mathrm{th}}=2.5 \mathrm{Mu}, \mathrm{Mu}=0.8\left(\mathrm{Pu}_{\mathrm{th}} / 2\right), \rho=\mathrm{As} / \mathrm{Ac}$

Then, $\mathrm{Pu}_{\mathrm{th}}=2.7 \mathrm{Fy}(1-0.9 \mathrm{Fy} / 105)$

$\mathrm{kg}$.

The theoretical values of the ultimate load for beams (without fibers) were $8.14 ; 11.91$ and 12.28 ton for bars type $\mathrm{Sm} ; \mathrm{B} \backslash \mathrm{S}$ and $\mathrm{EZ} \cdot \mathrm{AL} 2$, respectively .

The theoretical values of the cracking load (Pcrth) for beams without fibers can be

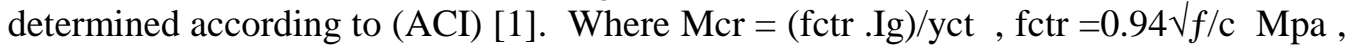
Mcr $=0.8$ (Pcrth. $/ 2)$, So, Pcrth $=2.5 \mathrm{Mcr}$. Then Pcrth $=3.81$ ton.

\section{- Influence of grade of steel and its relative rib area $\left(\alpha_{s b}\right)$}

The values of cracking $\left(\mathrm{P}_{\mathrm{cr}}\right)$ and the ultimate loads $\left(\mathrm{P}_{\mathrm{u}}\right)$ for tested beams increase with the increase of grade of steel bars represented by its yield stress and relative rib area $\left(\alpha_{\mathrm{sb}}\right)$ as shown in Table 5 and Fig. 11.

The values of cracking and the ultimate loads of bars (B\S) and (EZ.AL2) compared to the corresponding values of steel bar $(\mathrm{Sm})$ at different fibers were increased, respectively as follows:

\section{(a)-For cracking load}

For beams without fibers, by about 53.9 and $65.4 \%$, respectively.

For beams with polypropylene fibers, by about 63.2 and $80.3 \%$, respectively.

For beams with Harex steel fibers, by about 65 and $85.7 \%$, respectively.

\section{(b)-For ultimate load}

For beams without fibers, by about 57.8 and $76.6 \%$, respectively.

For beams with polypropylene fibers, by about 61 and $81.9 \%$, respectively.

For beams with H. steel fibers, by about 62 and $82.7 \%$, respectively.

Table 5: Values of cracking and ultimate loads for beams with and without fibers.

\begin{tabular}{|c|c|c|c|c|c|c|}
\hline $\begin{array}{c}\text { Group } \\
\text { No. }\end{array}$ & $\begin{array}{c}\text { Series } \\
\text { of } \\
\text { beams }\end{array}$ & $\begin{array}{c}\text { Relative } \\
\text { Rib Area } \\
\left(\alpha_{s b}\right)\end{array}$ & $\begin{array}{l}\text { Fiber } \\
\text { Types }\end{array}$ & $\begin{array}{l}\text { Pcr. } \\
\text { (ton) }\end{array}$ & $\begin{array}{l}\text { Pu. } \\
\text { (ton) }\end{array}$ & Mode of Failure \\
\hline \multirow{3}{*}{ A } & B1 & 0.00 & \multirow{3}{*}{$\begin{array}{l}\text { Without } \\
\text { fibers }\end{array}$} & 2.6 & 6.40 & Bond -Flexural Failure \\
\hline & $\mathrm{B} 2$ & 0.062 & & 4.0 & 10.10 & Flexural Failure \\
\hline & B3 & 0.100 & & 4.3 & 11.30 & Flexural Failure \\
\hline \multirow{3}{*}{ B } & $\mathrm{B} 1 \mathrm{P}$ & 0.00 & PP.F & 2.94 & 6.9 & Bond -Flexural Failure \\
\hline & $\mathrm{B} 2 \mathrm{P}$ & 0.062 & PP.F & 4.8 & 11.11 & Flexural Failure \\
\hline & B3P & 0.100 & PP.F & 5.3 & 12.55 & Flexural Failure \\
\hline \multirow{3}{*}{$\mathrm{C}$} & B1S & 0.00 & HS.F & 3.15 & 7.3 & Bond -Flexural Failure \\
\hline & B2S & 0.062 & HS.F & 5.2 & 11.82 & Flexural Failure \\
\hline & B3S & 0.100 & HS.F & 5.85 & 13.34 & Flexural Failure \\
\hline
\end{tabular}

Pcr and Pu : Experimental values of cracking and ultimate load 


\section{- Influence of fibers type}

The values of cracking $(\mathrm{Pcr})$ and ultimate loads $(\mathrm{Pu})$ for tested beams were more for beams with harex steel fibers than those of beams with polypropylene fibers. Also, they were more for beams with polypropylene fibers than those of beams without fibers as shown in Fig. 12. The values of cracking (Pcr) and ultimate (Pu) loads of beams made from (HPFRC) with harex steel and polypropylene fibers compared to the corresponding values of beams made from (HPC) without fibers with steel bars type $(\mathrm{Sm}),(\mathrm{B} \backslash \mathrm{S}$ ) and (EZ.AL2) were increased respectively as follows:

\section{(a) For cracking load}

For bar (Sm), by about 13.07 and $21.15 \%$, respectively.

For bar (B\S), by about 20.0 and $30.0 \%$, respectively

For bar (EZ.AL2), by about 23.2 and $36.04 \%$, respectively.

\section{(b) For ultimate load}

For bar (Sm), by about 7.8 and $14.08 \%$, respectively

For bar (B\S), by about 10 and $17.03 \%$, respectively.

For bar (EZ.AL2), by about 11.06 and $18.05 \%$, respectively.

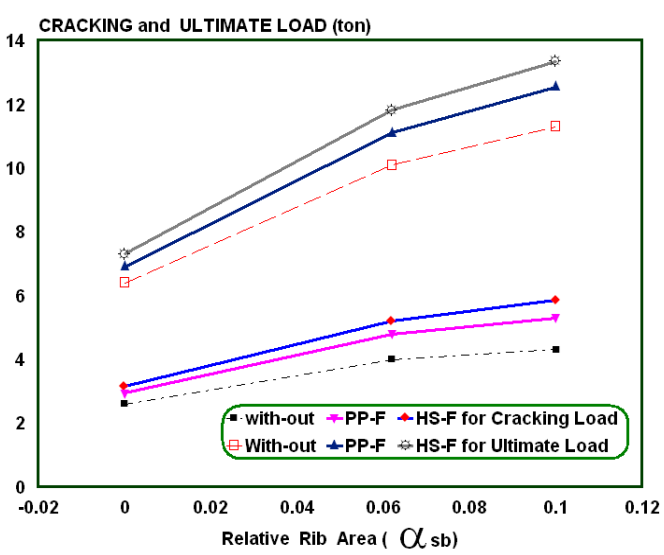

Fig (11): Cracking and ultimate loads of tested beams versus relative rib area of steel bars.

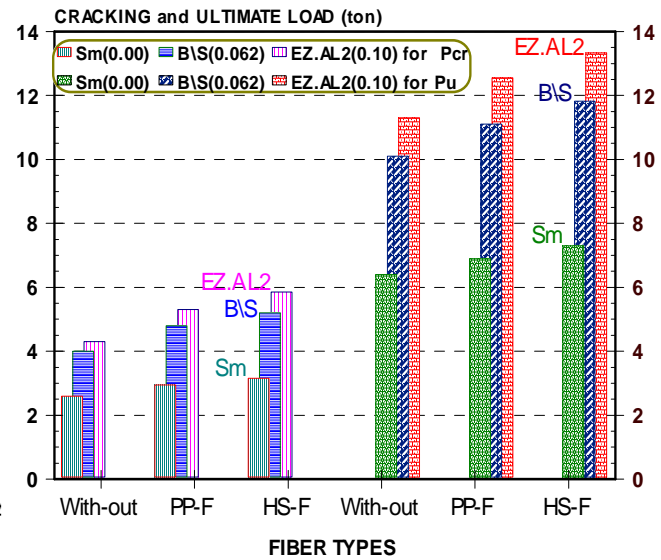

Fig 12: Cracking and ultimate loads of tested beams versus fibers type.

\section{2 Measured Deformations}

The values of the obtained deformation at cracking $\left(\mathrm{P}_{\mathrm{cr}}\right)$ and the ultimate loads $\left(\mathrm{P}_{\mathrm{u}}\right)$ for tested beams are given in Tables 6, 7, 8 and 9.The values of this deformation depend on the grade of steel and its relative rib area $\left(\alpha_{\mathrm{sb}}\right)$, and the fiber type.

\section{2.1 Mid-span deflections}

The values of deflection and the loads are considerably affected by the following parameters, as shown in Table 6 and Fig. 13. 
Table 6: Values of experimental deflection at cracking and ultimate loads and load at different values of deflection.

\begin{tabular}{|c|c|c|c|c|c|c|c|}
\hline \multirow{2}{*}{$\begin{array}{c}\text { Group } \\
\text { No. }\end{array}$} & \multirow[t]{2}{*}{ Series } & \multirow{2}{*}{$\begin{array}{l}\text { Fiber } \\
\text { Types }\end{array}$} & \multirow{2}{*}{$\begin{array}{c}\text { Relative } \\
\text { Rib Area } \\
\left(\alpha_{\mathrm{sb}}\right)\end{array}$} & \multicolumn{2}{|c|}{$\begin{array}{l}\text { Load (ton) at } \\
\text { Deflection }\end{array}$} & \multirow{2}{*}{$\begin{array}{c}\text { Deflection, } \\
(\mathrm{mm}) \text { at } P_{\mathrm{cr}} \\
\left(\delta_{\mathrm{cr}}\right)\end{array}$} & \multirow[t]{2}{*}{$\begin{array}{l}\text { Deflection, } \\
(\mathrm{mm}) \text { at } \mathrm{P}_{\mathrm{u}} \\
\quad\left(\delta_{\mathrm{u}}\right)\end{array}$} \\
\hline & & & & $0.5 \mathrm{~mm}$ & $5 \mathrm{~mm}$ & & \\
\hline \multirow{3}{*}{ A } & B1 & \multirow{3}{*}{$\begin{array}{l}\text { Without } \\
\text { Fiber }\end{array}$} & 0.000 & 0.87 & 4.72 & 1.34 & 16.21 \\
\hline & B2 & & 0.062 & 1.16 & 6.6 & 1.53 & 12.25 \\
\hline & B3 & & 0.100 & 1.30 & 7.12 & 1.62 & 11.3 \\
\hline \multirow{3}{*}{ B } & B1P & \multirow{3}{*}{ PP.F } & 0.000 & 1 & 5.07 & 1.27 & 15.25 \\
\hline & B2P & & 0.062 & 1.36 & 7.07 & 1.48 & 11.7 \\
\hline & B3P & & 0.100 & 1.57 & 8 & 1.53 & 10.9 \\
\hline \multirow{3}{*}{ C } & B1S & \multirow{3}{*}{ HS.F } & 0.000 & 1.2 & 5.25 & 1.23 & 14.75 \\
\hline & B2S & & 0.062 & 1.56 & 7.56 & 1.45 & 10.8 \\
\hline & B3S & & 0.100 & 1.78 & 9 & 1.47 & 10.5 \\
\hline
\end{tabular}

\section{-Influence of grade of steel and its relative rib area $\left(\alpha_{s b}\right)$}

At the same values of the deflections, the loads increase with the increase of grade of steel bar and its relative rib area $\left(\alpha_{\mathrm{sb}}\right)$. The loads were increased by different percentages ranged from $30 \%$ to $57 \%$ at deflection $=0.5 \mathrm{~mm}$. But, this increase ranged from $33 \%$ to $71.4 \%$ at deflection $=5 \mathrm{~mm}$.

At the cracking loads, deflection increases with the increase of the relative rib $\left(\alpha_{\mathrm{sb}}\right)$ due to increase of the cracking loads and constant stiffness of beams. The deflection was increased by different percentages ranging from 14.2 to $21 \%$.

At the ultimate loads, deflection decreases with the increase of the relative rib $\left(\alpha_{\mathrm{sb}}\right)$. The deflection was decreased by different percentages ranged from 23.3 to $30.3 \%$. The reduction of the values of deflection for the beams reinforced with steel bar (EZ.AL2), $(\mathrm{B} \backslash S)$ having $\left(\alpha_{\mathrm{sb}}=0.10,0.062\right)$ with higher values of yield stress may be due to the increase of the bond strength and the decrease of the slip resulting from the increase of the relative rib area $\left(\alpha_{\mathrm{sb}}\right)$ and the decrease in number, length and width of cracks. Therefore, the stiffness of these beams were more than the corresponding stiffness for beams reinforced with steel bar $(\mathrm{Sm})$ having $\left(\alpha_{\mathrm{sb}}=0.0 \& \mathrm{~F}_{\mathrm{y}}=3100 \mathrm{~kg} / \mathrm{cm}^{2}\right)$.

\section{-Influence of fibers type}

At the same values of deflection, the loads increase with the used fibers in reinforced concrete. The loads were increased by different percentages ranged from $15 \%$ to $37.9 \%$ for deflections $=0.5 \mathrm{~mm}$. Whereas these increases ranging from $7.1 \%$ to $26.4 \%$ for deflections $=5 \mathrm{~mm}$.

At the cracking load, deflection decreases with the used fibers in reinforced concrete. The deflection value was decreased by different percentages ranged from $3.27 \%$ to $9.3 \%$. At the ultimate loads, deflection decreases with the used fibers in reinforced concrete. The deflection value was decreased by different percentages ranged from 
$3.5 \%$ to $11.84 \%$.The decrease of deflection with the used fibers in reinforced concrete resulting to decrease of slip and increase of bond strength, which accompanied with the decrease of length and width of cracks. Therefore, the stiffness of these beams with the used fibers in reinforced concrete were more than those for beams without fibers as shown in Fig. 14.

Table 7: Values of slip at cracking and ultimate loads and loads at different slips.

\begin{tabular}{|c|c|c|c|c|c|c|c|}
\hline $\begin{array}{c}\text { Group } \\
\text { No. }\end{array}$ & Series & $\begin{array}{l}\text { FIBER } \\
\text { TYPES }\end{array}$ & $\begin{array}{c}\text { Relative } \\
\text { Rib } \\
\text { Area }\left(\alpha_{s b}\right)\end{array}$ & $\begin{array}{r}\text { Load, } \\
\text { Slip } \\
0.025\end{array}$ & $\begin{array}{l}\text { ton) at } \\
(\mathrm{mm}) \\
0.25\end{array}$ & $\begin{array}{l}\text { Slip, }(\mathrm{mm}) \\
\quad \text { at } P_{c r}\end{array}$ & $\begin{array}{l}\text { Slip, }(\mathrm{mm}) \\
\text { at } \mathrm{P}_{\mathrm{ul}}\end{array}$ \\
\hline \multirow{3}{*}{ A } & B1 & \multirow{3}{*}{$\begin{array}{l}\text { Withou } \\
\text { t Fiber }\end{array}$} & 0.000 & 0.08 & 0.75 & 0.81 & 2.25 \\
\hline & B2 & & 0.062 & 0.17 & 2.05 & 0.47 & 1.34 \\
\hline & B3 & & 0.100 & 0.24 & 2.65 & 0.40 & 1.19 \\
\hline \multirow{3}{*}{ B } & B1P & \multirow{3}{*}{ PP.F } & 0.000 & 0.12 & $1 . .17$ & 0.67 & 1.90 \\
\hline & B2P & & 0.062 & 0.36 & 3.86 & 0.32 & 1.09 \\
\hline & B3P & & 0.100 & 0.5 & 4.8 & 0.28 & 0.96 \\
\hline \multirow{3}{*}{ C } & B1S & \multirow{3}{*}{ HS.F } & 0.000 & 0.16 & 1.5 & 0.58 & 1.75 \\
\hline & B2S & & 0.062 & 0.41 & 4.51 & 0.29 & 0.95 \\
\hline & B3S & & 0.100 & 0.63 & 5.85 & 0.25 & 0.84 \\
\hline
\end{tabular}

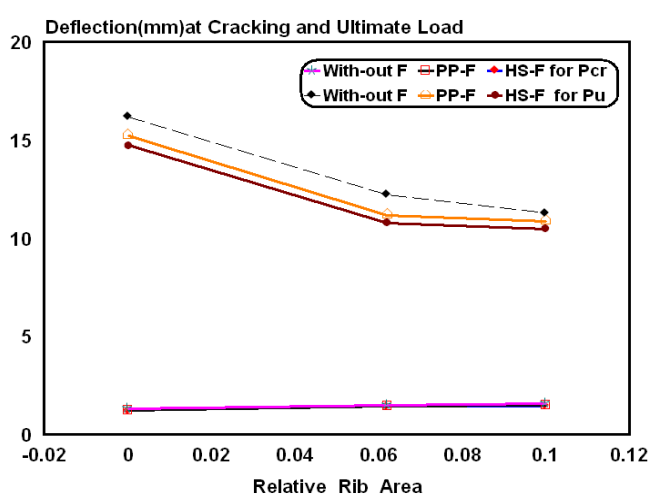

Fig. 13: Deflection at cracking and ultimate load versus relative rib area of tested beams.

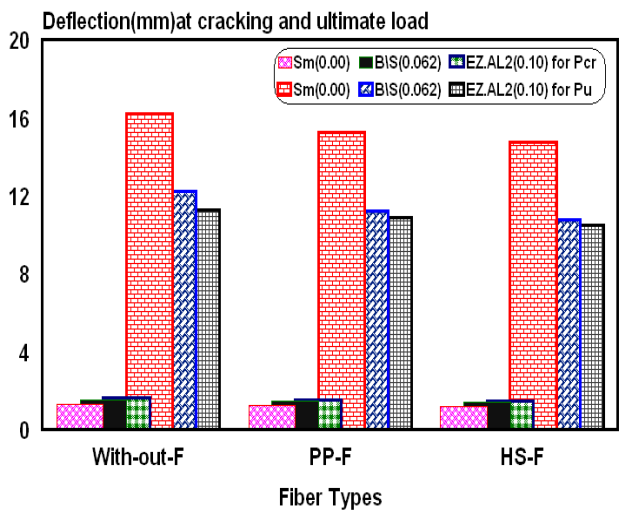

Fig. 14: Deflection at cracking and ultimate load versus fibers type of tested beams.

\section{2. 2 End slip of steel}

The values of slip at cracking and ultimate loads and the loads are considerably affected by the following parameters: -

\section{- Influence of grade of the main steel and its relative rib area $\left(\alpha_{s b}\right)$}

The measured end slip of steel bars of tested beams as affected by grade of steel or its relative rib area are shown in Table 7 and Fig. 15. At the same values of the slip, the loads increase with the increase of the relative rib area $\left(\alpha_{\mathrm{sb}}\right)$ due to increase of the bond 
strength $\left(\mathrm{f}_{\mathrm{b}}\right)$. The loads were increased by different percentages ranged from $112.5 \%$ to $317 \%$ for slip $=0.025 \mathrm{~mm}$ and from $110 \%$ to $285 \%$ for slip $=0.25 \mathrm{~mm}$. At the same values of loads, the slip decreases with the increase of the grade of steel and its relative rib area $\left(\alpha_{\mathrm{sb}}\right)$ due to increase of the bond strength $\left(\mathrm{f}_{\mathrm{b}}\right)$.

At the cracking and the ultimate loads, the slip decreases with the increase of the relative rib area $\left(\alpha_{\mathrm{sb}}\right)$. The slip were decreased by different percentage ranged from $50.4 \%$ to $56.9 \%$ for the cracking loads and from $47.1 \%$ to $52 \%$ for the ultimate loads. The decrease due to increase of the bond strength and the decrease in number, length and width of cracks. Therefore, the stiffness of the cross-section of beams was increased.

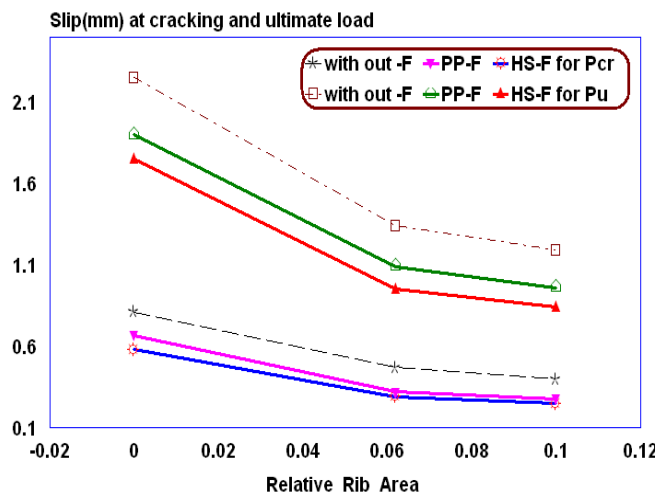

Fig. 15: Slip at cracking and ultimate load versus relative rib area of steel bar for tested beams.

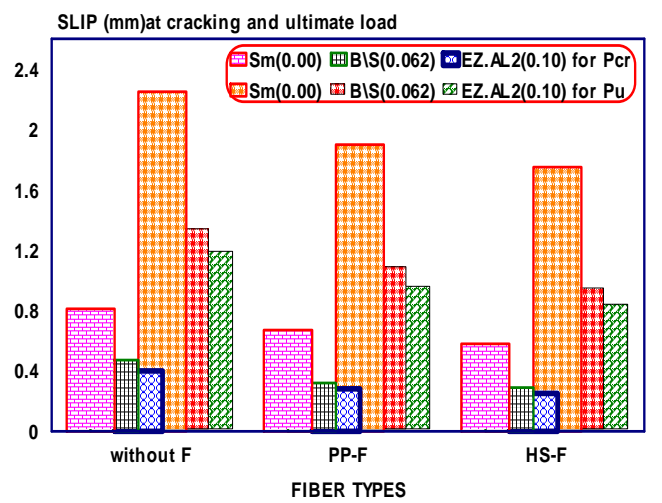

Fig. 16: Slip at Cracking and Ultimate Load versus fiber types for tested beams.

\section{- Influence of fibers type}

The measured end slip for steel bars of tested beams with and without fibers are shown in Fig. 16 and Table 7. At the same values of slip, the loads increase with the used fibers in (HPC). They increased by different percentages ranged from 50\% to163\% for slip $=0.025 \mathrm{~mm}$ and from $56 \%$ to $102.7 \%$ for slip $=0.25 \mathrm{~mm}$.

At cracking load, the slip decreases with the used fibers in (HPC) by different percentages ranged from $17.3 \%$ to $38.3 \%$. At the ultimate load, the slip decreases with the used fibers in (HPC) by different percentages ranged from $15.56 \%$ to $37.5 \%$. The measured end slip for tested beams group (C), of harex steel fibers, were less than that measured for group (B) of polypropylene fibers. A1so, the measured end slip for tested beams group (B) having polypropylene fibers were less than that measured for tested beams group (A) without fibers.

\section{2. 3 Concrete strain}

The values of concrete strain are measured at top surface of the compression zone corresponding to the relative rib area $\left(\alpha_{\mathrm{sb}}\right)$, fiber types, cracking and ultimate loads and shown in Table 8. The values of concrete strain at cracking and ultimate loads and the loads are considerably affected by the following parameters: 
Table 8 : Values of concrete strain at cracking and ultimate loads and loads at concrete strain $=0.07,0.7 * 10^{-3} \mathrm{~m} / \mathrm{m}$.

\begin{tabular}{|c|c|c|c|c|c|c|c|}
\hline \multirow{2}{*}{$\begin{array}{c}\text { Group } \\
\text { No. }\end{array}$} & \multirow[t]{2}{*}{ Series } & \multirow{2}{*}{$\begin{array}{l}\text { Fiber } \\
\text { Types }\end{array}$} & \multirow{2}{*}{$\begin{array}{c}\text { Relative Rib } \\
\operatorname{Area}\left(\alpha_{\mathrm{sb}}\right)\end{array}$} & \multicolumn{2}{|c|}{\begin{tabular}{|} 
Load (ton) at Strair \\
${ }_{*} \mathbf{1 0}^{-3}$
\end{tabular}} & \multirow{2}{*}{$\begin{array}{l}\text { Strain } \times 10^{-3} \\
\text { at } P_{c r}\end{array}$} & \multirow{2}{*}{$\begin{array}{l}\text { Strain } \\
* 10^{-3} \\
\text { at } \mathrm{P}_{\mathrm{u}}\end{array}$} \\
\hline & & & & $\begin{array}{l}0.07 \\
\end{array}$ & 0.70 & & \\
\hline \multirow{3}{*}{$\mathbf{A}$} & B1 & \multirow{3}{*}{$\begin{array}{l}\text { Without } \\
\text { fibers }\end{array}$} & 0.000 & 1.0 & 6.2 & 0.18 & 0.75 \\
\hline & B2 & & 0.062 & 1.75 & 7.28 & 0.24 & 1.29 \\
\hline & B3 & & 0.100 & 2.0 & 7.59 & 0.25 & 1.46 \\
\hline \multirow{3}{*}{ B } & B1P & \multirow{3}{*}{ PP.F } & 0.000 & 1.2 & 6.38 & 0.20 & 0.85 \\
\hline & B2P & & 0.062 & 2 & 7.53 & 0.25 & 1.45 \\
\hline & B3P & & 0.100 & 2.25 & 8 & 0.28 & 1.62 \\
\hline \multirow{3}{*}{ C } & B1S & \multirow{3}{*}{ HS.F } & 0.000 & 1.5 & 6.6 & 0.21 & 0.93 \\
\hline & B2S & & 0.062 & 2.2 & 7.76 & 0.26 & 1.56 \\
\hline & B3S & & 0.100 & 2.4 & 8.41 & 0.30 & 1.69 \\
\hline
\end{tabular}

\section{- Influence of grade of main steel and its relative rib area $\left(\alpha_{s b}\right)$}

Influence of grade of steel represented by its relative rib area on the concrete strain of all tested beams is shown in Fig. $\mathbf{1 7}$ and Table 8. At the same values of strain, the loads increase with the increase of the relative rib area $\left(\alpha_{\mathrm{sb}}\right)$ by different percentages ranged from $46.7 \%$ to $100 \%$ for strain $=0.07 * 10^{-3}$ and from $17.4 \%$ to $27.4 \%$ for strain $=0.7 * 10^{-3}$. This increase due to the decrease of slip, length and width of cracks.

At cracking load, the concrete strain increases with the increase of the relative rib area $\left(\alpha_{\mathrm{sb}}\right)$ by different percentages ranged from $23.8 \%$ to $42.8 \%$. At the ultimate load, concrete strain increases with the increase of the relative rib area $\left(\alpha_{\mathrm{sb}}\right)$ by different percentages ranged from $67.8 \%$ to $94.7 \%$.

The increase of the values of concrete strain at cracking and ultimate loads for beams reinforced with steel bar having more relative rib area $\left(\alpha_{\mathrm{sb}}\right)$ may be due to the bond strength increase and decrease of the slip between main steel and concrete for beams resulting from the decrease in length and width of cracks. Therefore, the stiffness of these beams were more than the beam with main steel of less relative rib area $\left(\alpha_{\mathrm{sb}}\right)$.

\section{- Influence of fibers type}

Influence of fibers type on the concrete strain of all tested beams is shown in Fig. 18 and Table 8. At the same values of strain, the loads increase with the used fibers in (HPC) by different percentages ranged from $20 \%$ to $50 \%$ at strain $=0.07 * 10^{-3}$ and ranged from $3 \%$ to $1.8 \%$ at strain $=0.7 * 10^{-3}$. At cracking load, the strain increases with the used fibers in (HPC) by different percentage range ranged from $4.16 \%$ to $20 \%$. At ultimate load, the strain increases with the used fibers in (HPC) by different percentages ranged from $10.95 \%$ to $24 \%$ compared to those without fibers.

At cracking and ultimate loads, the values of concrete strain increase for beams with polypropylene and harex steel fibers than beams without fibers. Also the values of concrete strain increase for beams with harex steel fibers than beams with 
polypropylene fibers. The increase of the values of concrete strain at cracking and ultimate loads for beams with polypropylene and harex steel fiber may be due to the increase of bond strength and decrease of slip between main steel and concrete resulting from the decrease in length and width of cracks. Therefore, the stiffness of these beams became more than that of beams without fibers.

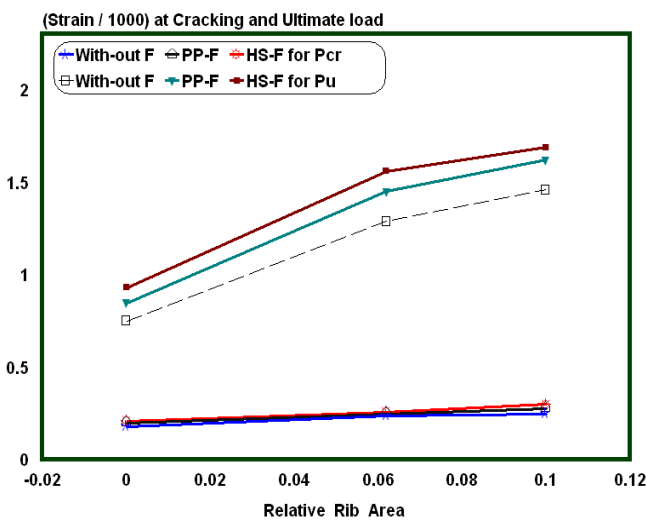

Fig. 17: Concrete strain at cracking and ultimate load versus relative rib area of tested beams.

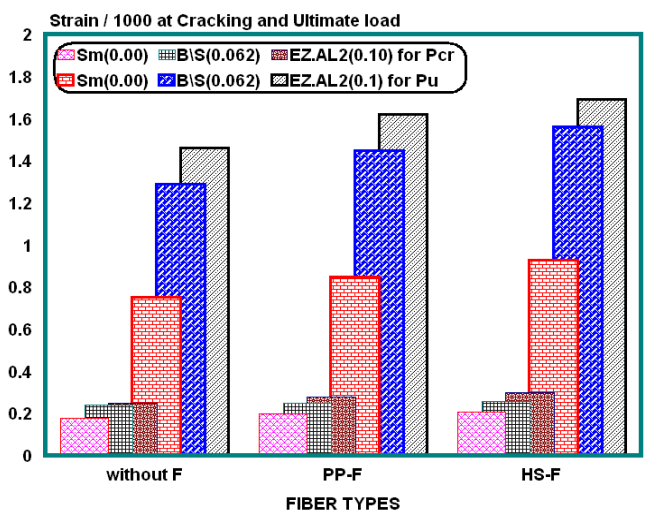

Fig. 18: Concrete strain at cracking and ultimate load versus fibers type for tested beams.

\section{2. 4 End slope of tested beams}

The measured values of slope at the support of the beams corresponding to the point of maximum slope at cracking and ultimate loads are recorded in Table 9. The values of slope at the cracking and the ultimate loads and the loads at different slopes are considerably affected by the following parameters:

\section{- Influence of grade of main steel and its relative rib area $\left(\alpha_{s b}\right)$}

Influence of grade of steel represented by its relative rib area on the end slope of all tested beams is shown in Fig. 19 and Table 9. At the same values of slope the values of loads increase with the increase of grade of steel and its relative rib area $\left(\alpha_{\mathrm{sb}}\right)$. At the cracking loads, the slope of tested beams at the support increased with the increase of the relative rib area $\left(\alpha_{\mathrm{sb}}\right)$ due to the increase of cracking loads and constant stiffness of the cross-section of the beam. At the ultimate loads, the slope of beams at the support decreased also with the increase of the relative rib area $\left(\alpha_{\mathrm{sb}}\right)$ and grade of steel due to the decrease of slip and increase of bond strength, which causes a decrease in length, and width of cracks.

\section{- Influence of fibers type}

Influence of fibers type on the end slope of all tested beams is shown in Fig. 20 and Table 9. At constant slope, the values of load carrying capacity of beams increase with the used fibers due to increase of bond strength and decrease of slip which causes decrease in length, width of cracks and increase stiffness of the cross-section of the beam. 
At the cracking load, the slope values for beams increase with the used fibers due to increase of cracking load and constant value of stiffness of the beam. The reduction of the values of slope at ultimate loads for beams with harex fibers are due to the increase of bond strength and decrease of slip which causes decrease in length, width of cracks and increase the cross-section stiffness of the beams.

Table 9: Values of slope at cracking and ultimate loads and loads at different slopes.

\begin{tabular}{|c|c|c|c|c|c|c|c|}
\hline $\begin{array}{c}\text { Group } \\
\text { No. }\end{array}$ & Series & \multirow{2}{*}{$\begin{array}{c}\text { Type of } \\
\text { fiber }\end{array}$} & $\begin{array}{c}\text { Relative } \\
\text { Rib Area } \\
\left(\alpha_{\text {sb }}\right)\end{array}$ & \multicolumn{2}{|c|}{$\begin{array}{c}\text { Load,(ton) at } \\
\text { Slope, (radian) }\end{array}$} & $\begin{array}{c}\text { Slope } * 10^{-3} \\
\text { at cracking }\end{array}$ & $\begin{array}{c}\text { Slope } * 10^{-3} \\
\text { at ultimate } \\
\text { load }\left(\mathrm{P}_{\mathrm{cr}}\right)\end{array}$ \\
load $\left(\mathrm{P}_{\mathrm{u} 0}\right)$
\end{tabular}

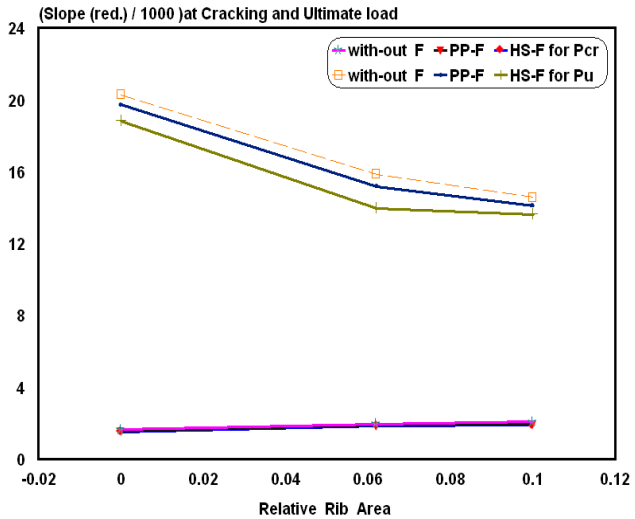

Fig. 19: Slope at cracking and ultimate load versus relative rib area for tested beams.

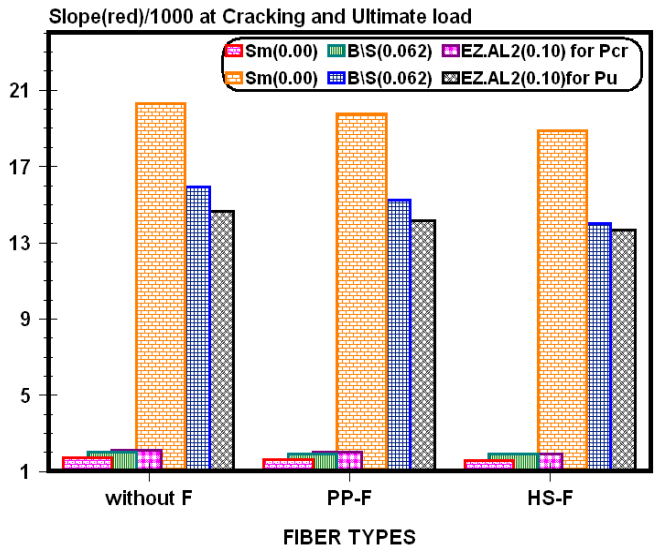

Fig. 20: Slope at cracking and ultimate load versus fiber types for tested beams.

\section{CONCLUSIONS}

1. The shape of rib geometry of steel bars represented by its relative rib area $\left(\alpha_{\mathrm{sb}}\right)$ has a very small effect on their mechanical properties especially yield stress and ultimate strength and the main influence depends on the grade of steel.

2. The shape of rib geometry has a clear influence on the ultimate bond strength of tested specimens, which increased by about $139 \%$ by the increase of the relative rib area from 0.0 to 0.10 and not mainly depended on the yield stress of steel bars. 
3. The first crack was early observed for (HPFRC) beams with main steel bars having smaller values of yield stress and relative rib area $\left(\alpha_{\mathrm{sb}}\right)$ and also for beams without fibers.

4. The width of cracks and spacing between them were significantly large for beams having smooth bars, but narrow for other beams having ribbed bars. The propagation of cracks for beams reinforced with ribbed bars were more than those of beams reinforced with smooth bars.

5. The values of cracking and ultimate load carrying capacity of R.C. tested beams were increased with the increase of the yield stress and relative rib areas of main steel $\left(\alpha_{\mathrm{sb}}\right.$ from 0.0 to 0.10$)$ by about $65 \& 76 \%$ respectively for beams without fibers. Also, they were increased by about $80 \& 82 \%$ for beams with polypropylene fibers and by about $86 \& 83 \%$ for beams with harex steel fibers.

6. Adding fibers to the concrete mixes of (HPC) beams showed consistent higher first cracking and higher ultimate loads than those without fibers. Also adding harex steel fibers to the high strength R.C. beams showed consistent higher first cracking and ultimate loads than those of beams with polypropylene fiber.

7. The values of the deflection, strain, slip and end slope at free end of tested beams were decreased with the increase of the yield stress and relative rib area $(\alpha s b)$ of the main steel.

8. Adding fibers to the concrete mixes of (HPC) beams showed smaller values of deflection, strain, slip and slope than those of beams without fibers. Also, they were less for beams with harex steel fibers than those of beams with polypropylene fibers.

9. The addition of fibers to concrete mixes of R.C. beams has greatly improved their ductility by increasing the ultimate strains under maximum compressive stresses and improved the crack propagation patterns for all tested (HPFRC) beams.

10. High strength fiber R.C. beams showed smaller crack widths and numbers compared to high strength R.C. beams without fibers at the same loading levels. Also, tested beams with harex steel fibers showed smaller crack widths and numbers compared to test beams with polypropylene fibers at the same loading levels.

\section{REFERENCES}

[1] ACI 318R-95,"Building code Requirement for structure concrete and commentary", American concrete Institute, Detroit, Michigam,1995.

[2] Hosny M. Soghair, Mohamed M. Rashwan, Aly Abdel-Zaher Elsayed and Ali Mohamed Abdallah, "Effect of rib geometry of steel bars on bond strength for high performance concrete ', Journal of Engineering Sciences, Assiut University, Vol.33, No. 5, pp.1733-1748, September 2005.

[3] Noumowe, "Mechanical properties and microstructure of high strength concrete containing polypropylene fibers exposed to temperature up to $200^{\circ} \mathrm{c}$ ", Cement and Concrete Research, Vol. 35, Issue 11, November 2005, pp.2192-2198.

[4] K. B. Lub and M. S. Mathews, "Influence of steel fibers on the behavior of conventionally reinforced thin-walled hollow beams' International Journal of Cement Composites and Light Concrete, Vol. 11, Issue 1, February 1989, p. 47. 
[5] P. N. Balaguru and S. P. Shah. (1992). Fiber Reinforced Cement Composites. McGraw-Hill, New York, 1992, xii, 530 pp.

[6] C. Fritz, A. E. Naaman, and D.H.W. Reinhardt. (1992). Sifcon Matrix in RC Beams. Proceedings of the RILEM-ACI International Workshop, held June 2326, 1991, Mainz, Germany; Ed. by H. W. Reinhardt and A. E. Naaman, E \& FN Spoon, London, pp. 518-528.

[7] M. H. Harajli and M. E. Mabsout (2002) M. H. Harajli and M. E. Mabsout (2002) "Evaluation of Bond Strength of Steel Reinforcing Bars in Plain and Fiber-Reinforced Concrete" ACI Structural Journal , July (2002)Vol. 99, No. 4.

[8] Magdy A. Tayel et al (2003)“ Experimental study on steel fiber-reinforced concrete beams "Tenth international colloquium on structural and geotechnical engineering April 22-24 , (2003), Ain Shams University, Cairo , Egypt) .

[9] Ali M. Abdallah "Effect of rib geometry for steel reinforcements on bond characteristics and rotational capacity of exterior joints in structures " M.sc.thesis. Assiut university, (2000) .

[10] Rehm, G, Eligehausen and Neubert, B.Erlauterung der Bewehrungsrichtlinien (Rationale for the detailing provisions of DIN 1045) Deutscher Ausschuss Fur Stahlbeton, Heft 300,1979.

[11] Soretz, S., Holzenbein, H., " Einflu $\beta$ der Rippenabmessungen von Betonbewehrungsstaben auf den Verbund und die Biegefahigkeit " Betonstahl in Entwicklung. Tor-Isteg Steel Corporation. Luxenburg, Heft 69, 1980.

[12] Parviz Soroushian, Ki-Bong Choi, Gill-Hyun , and Farhang Asiani " Bond of Deformed Bars to Concrete Effects of Confinement and Strength of Concrete .ACI Materials Journal V. 88 No.3 , May -June 1991.

[13] F. de Larrard, I. Schaller, and J. Fuchs. (1993). Effect of Bar Diameter on the Bond Strength of Passive Reinforcement in High-Performance Concrete. ACI Materials Journal, Jul-Aug, Vol. 90, No. 4, p. 333.

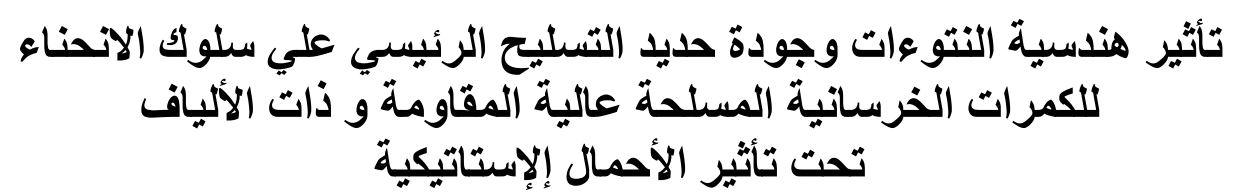

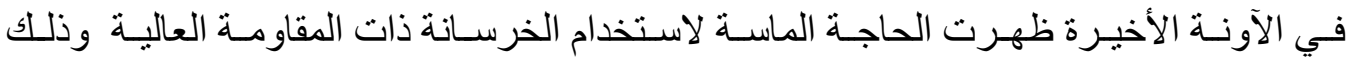

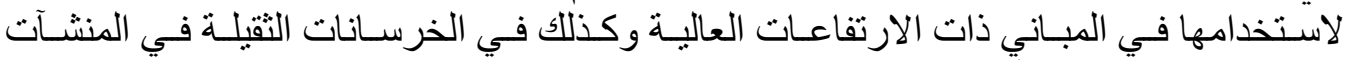

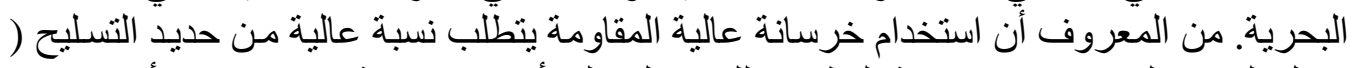

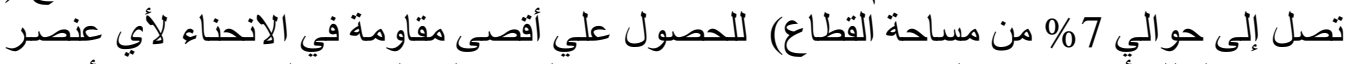

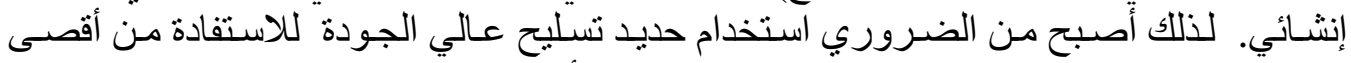

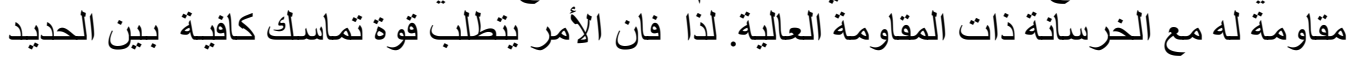

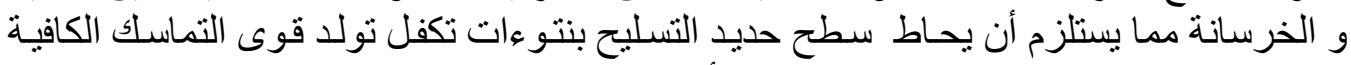

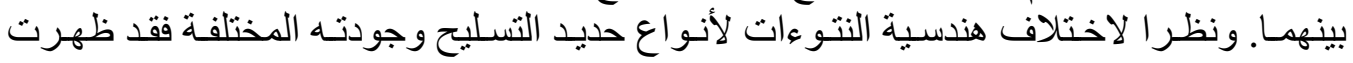

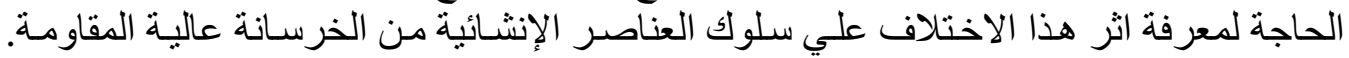




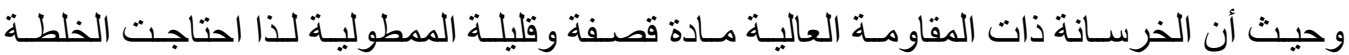

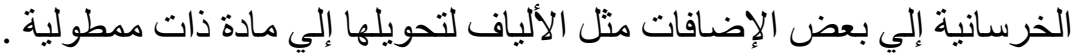

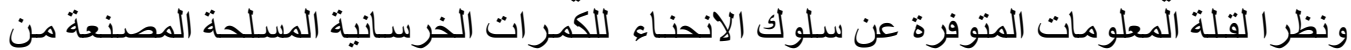

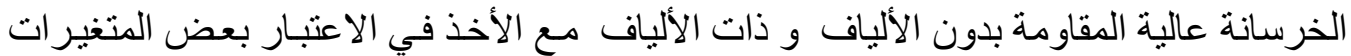

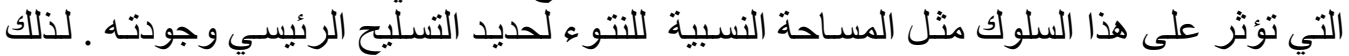

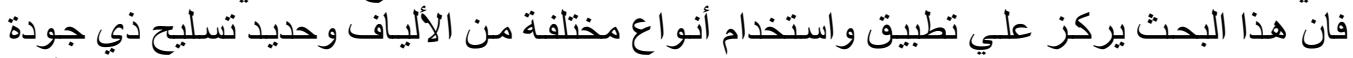

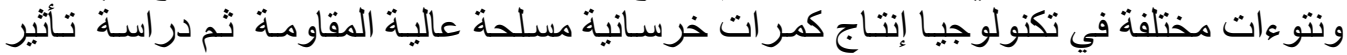

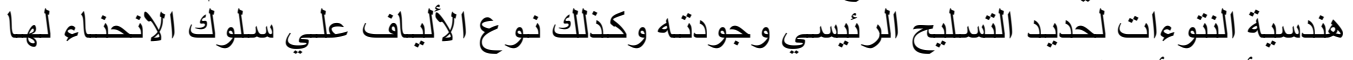
تحت تأثير الأحمال الاستاتيكية.

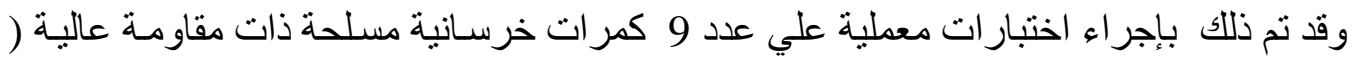

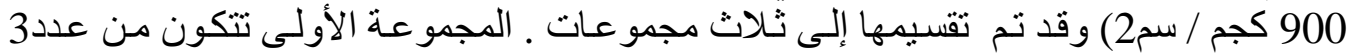

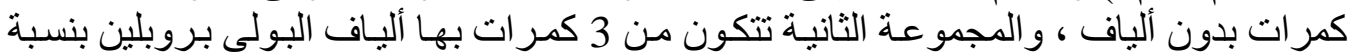

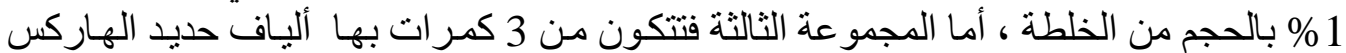

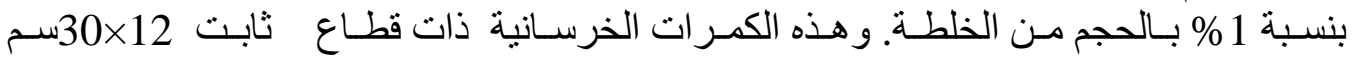
وتسليح سفلى رئيسي = 16Ø2مم و علوي

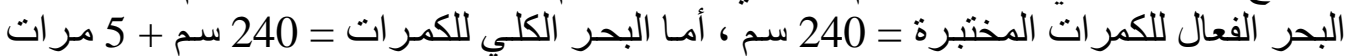
قطر السيخ من كل جانب. و قد نم الآخذ في الاعنبار المتغيرات التالية التالية :

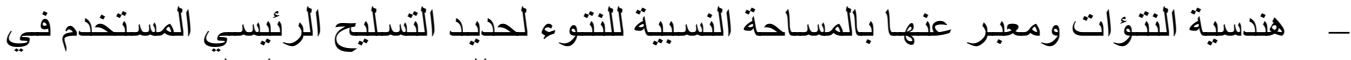

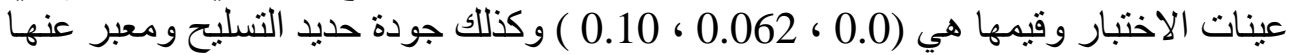

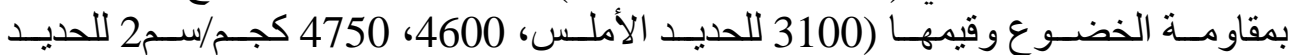

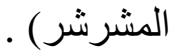

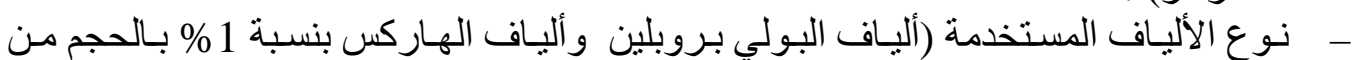

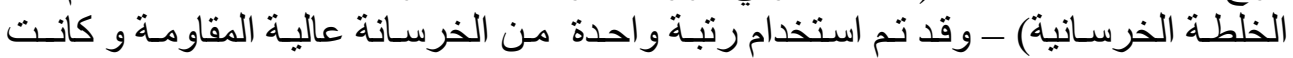
قيمتها هي (900 كجم/سم²) ، وكذللك نسبة واحدة من تركيز الألياف للخلطة وذلكة ولك لمقارنـة النتائج.

وقد تم التوصل لنتائج هامة في هذا البحث منها ما يلي :

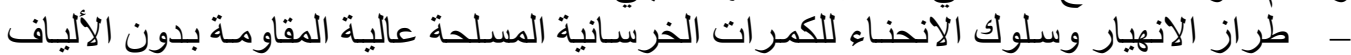

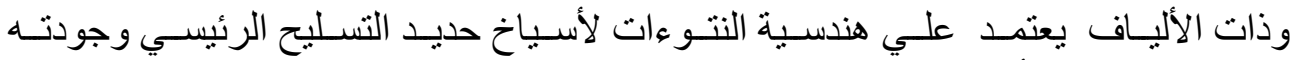

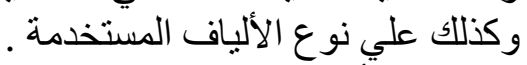

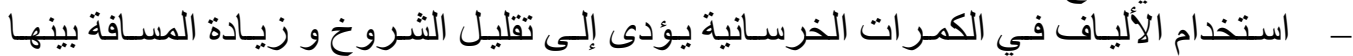

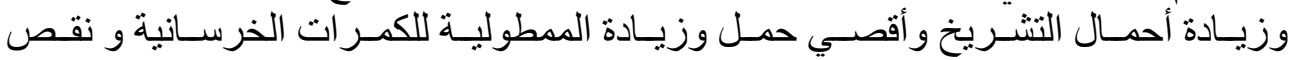

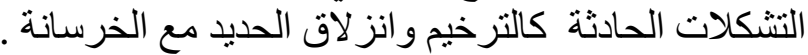

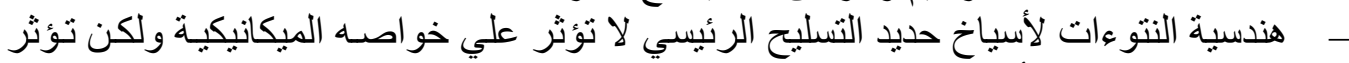

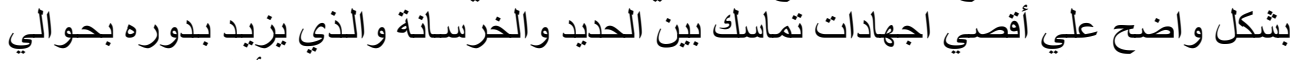
139\% بزيادة المساحة النسبية للنتو ء إلي 0.10 بالمقارنة بعينات الحديد الأملس. 